\title{
Thrust tectonics in the Wetterstein and Mieming mountains, and a new tectonic subdivision of the Northern Calcareous Alps of Western Austria and Southern Germany
}

\author{
Hugo Ortner ${ }^{1} \mathbb{D} \cdot$ Sinah Kilian ${ }^{1,2}$
}

Received: 14 September 2021 / Accepted: 26 October 2021 / Published online: 20 November 2021

(c) The Author(s) 2021

\begin{abstract}
We investigate the tectonic evolution of the Wetterstein and Mieming mountains in the western Northern Calcareous Alps (NCA) of the European Eastern Alps. In-sequence NW-directed stacking of thrust sheets in this thin-skinned foreland thrust belt lasted from the Hauterivian to the Cenomanian. In the more internal NCA major E-striking intracontinental transform faults dissected the thrust belt at the Albian-Cenomanian boundary that facilitated ascent of mantle melts feeding basanitic dykes and sills. Afterwards, the NCA basement was subducted, and the NCA were transported piggy-back across the tectonically deeper Penninic units. This process was accompanied by renewed Late Cretaceous NW-directed thrusting, and folding of thrusts. During Paleogene collision, N(NE)-directed out-of-sequence thrusts developed that offset the in-sequence thrust. We use this latter observation to revise the existing tectonic subdivision of the western NCA, in which these out-of-sequence thrusts had been used to delimit nappes, locally with young-on-old contacts at the base. We define new units that represent thrust sheets having exclusively old-on-young contacts at their base. Two large thrust sheets build the western NCA: (1) the tectonically deeper Tannheim thrust sheet and (2) the tectonically higher Karwendel thrust sheet. West of the Wetterstein and Mieming mountains, the Imst part of the Karwendel thrust sheet is stacked by an out-of-sequence thrust onto the main body of the Karwendel thrust sheet, which is, in its southeastern part, in lateral contact with the latter across a tear fault.
\end{abstract}

Keywords Tectonic subdivision · Thrust kinematics · Out-of-sequence thrusts · Eastern Alps · Zugspitze

\section{Introduction}

The NCA are the most northern and external part of the fartravelled Austroalpine nappe system of the Eastern Alps, and are a typical thin-skinned fold-and-thrust belt (e.g., Linzer et al. 1995; Eisbacher and Brandner 1996; Schmid et al. 2004). The NCA thrust sheets and nappes were stacked and emplaced on tectonically deeper units mainly during the Cretaceous (see "Structural evolution of the NCA"). In three seminal papers Hahn $(1912,1913 a, b)$ subdivided the NCA from external to internal and base to top into the Bajuvaric, Tirolic, and Juvavic nappe systems (Fig. 1). He also

Hugo Ortner

hugo.ortner@uibk.ac.at

1 Institut für Geologie, Universität Innsbruck, Innrain 52, 6020 Innsbruck, Austria

2 Present Address: Labour Inspectorate Tirol, Innsbruck, Austria described the different Triassic facies within these nappe systems: the Bajuvaric nappes have the smallest sedimentary thicknesses, dominantly shallow marine facies, and local clastic intercalations in the carbonate-dominated successions. The maximum sedimentary thickness is found in the entirely carbonatic shallow marine successions of the Tirolic nappe system. The Juvavic nappe system has two different parts: (i) Sedimentary facies within the Lower Juvavic units varies from pelagic limestones (Hallstatt facies) to forereef and reef facies (Hahn 1913b; Gawlick et al. 1999; Mandl 2000; Frisch and Gawlick 2003). The Lower Juvavic units represent swarms of slides initially emplaced in the Late Jurassic that were covered by younger deposits and locally remobilized during Cretaceous thrusting (Tollmann 1987; Mandl 2000; Gawlick and Missoni 2015). The (ii) Upper Juvavic nappes have the same carbonatic shallow marine successions as the Tirolic nappe system. Only in the 1980s, it was understood that these facies zones were part of a south-facing passive continental margin and represent the transition from the inner continental margin to the 


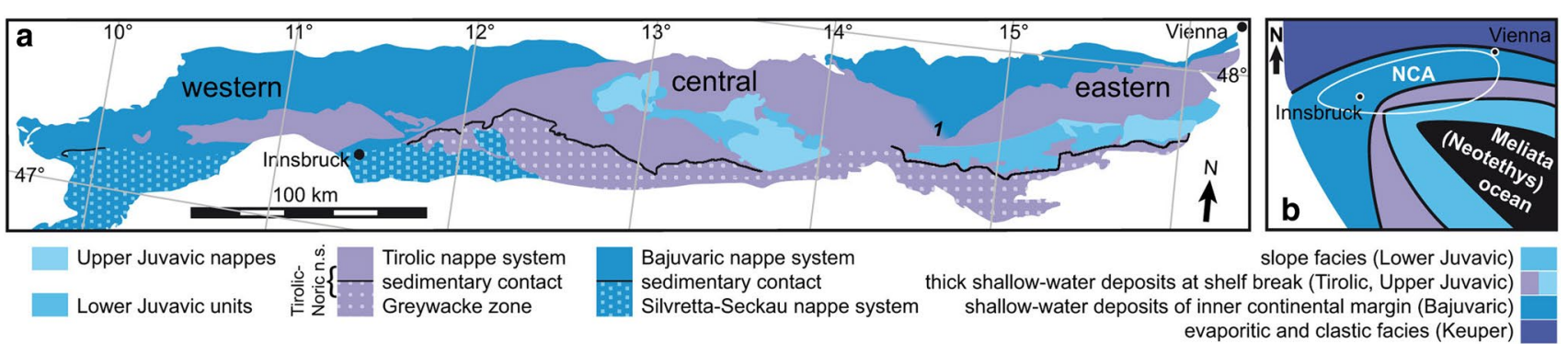

Fig. 1 a Nappe systems of the Northern Calcareous Alps as proposed by Tollmann (1976b). Primary sedimentary contacts to underlying basement units are emphasized by black lines. Label 1 marks an area where the thrust between the Tirolic and the Bajuvaric nappe sys-

continental slope (Fig. 1) that was stacked during Alpine orogeny (Brandner 1984; Lein 1987; Haas et al. 1995; Mandl 2000). In the western NCA; however, facies boundaries turn toward a N-S direction (Fig. 1b), and all units stacked have the same facies of an inner continental margin (Bechstädt and Mostler 1976; Tollmann 1976a; Haas et al. 1995).

Based on the work of Ampferer and Hammer (1911) and Ampferer (1912), the western NCA have been subdivided into three major thrust sheets (Figs. 2, 3b): These are, from base to top, the (1) Allgäu thrust sheet, forming a narrow band at the northern margin of the NCA, except in the far tems ends in an anticline (Tollmann 1976b). b Facies of the Eurasian continental margin against the Meliata embayment of the Neotethys ocean in the Upper Triassic (simplified from Haas et al. 1995). "western", "central" and "eastern" refers to the respective parts of the NCA

west, the (2) Lechtal thrust sheet, representing the main body of the western NCA, and the (3) Inntal thrust sheet in the south-central part of the NCA of Tirol (Heißel 1958; Tollmann 1970b, 1976b; Eisbacher and Brandner 1996). Even more external than the Allgäu thrust sheet, a narrow, discontinuous marginal slice named the "Cenoman-Randschuppe" (CRS) is present (Figs. 2,3) that accompanies the NCA over much of its length (Tollmann 1970b; Müller 1973). On top of the Inntal thrust sheet, the Krabachjoch thrust sheet is preserved in isolated klippen between Lech and Imst (Fig. 2) (Ampferer 1914b). Even if the sedimentary succession of

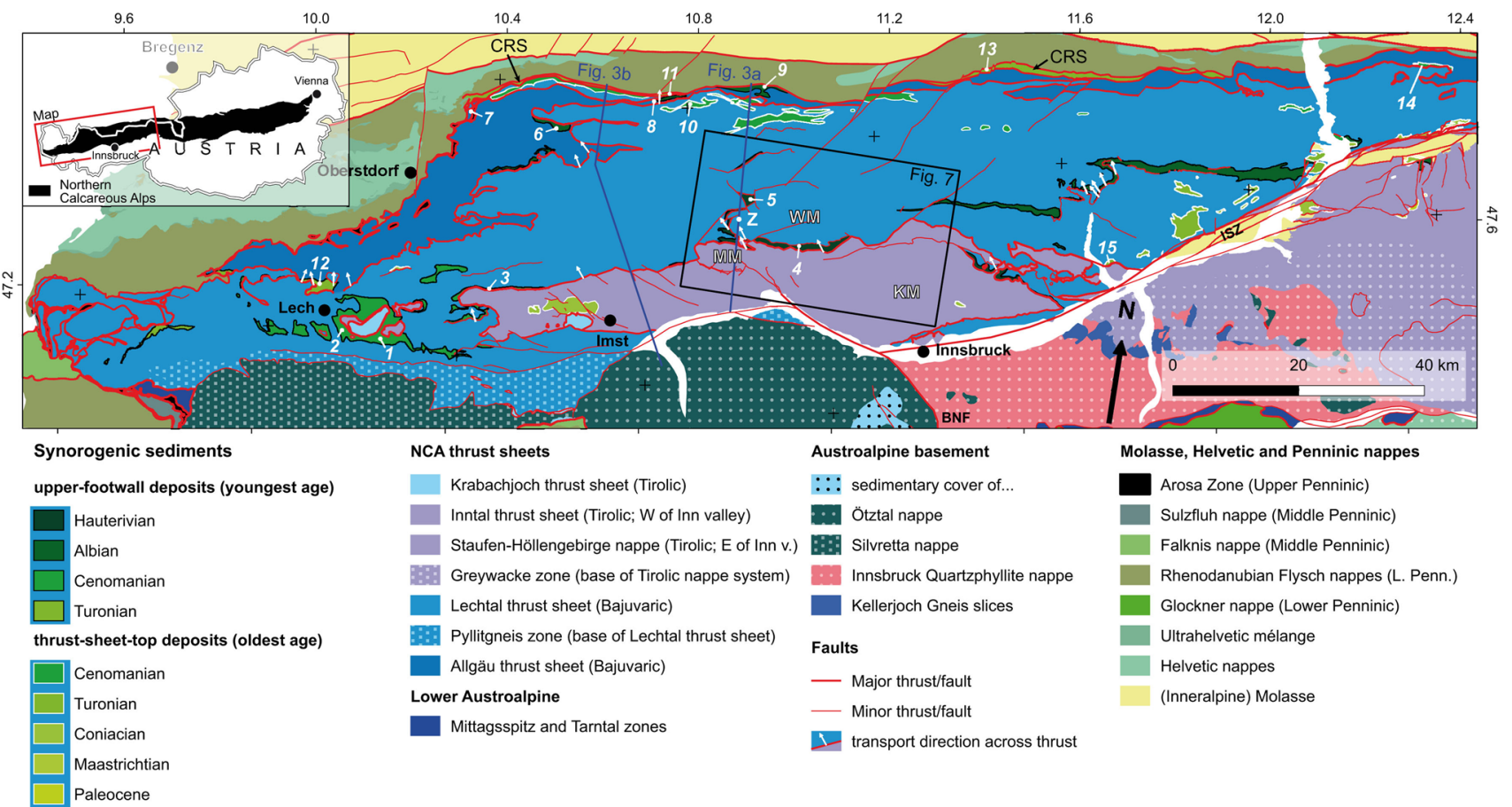

Fig. 2 Tectonic map of the western Northern Calcareous Alps following Heißel (1958) and Tollmann (1970a, 1976b). Synorogenic deposits are distinguished into upper-footwall- and thrust sheet-top deposits (Ortner 2003a, 2016; Ortner and Gaupp 2007) that allow to recon- struct the timing of thrust sheet emplacement (see text and Fig. 4). $\mathrm{Z}=$ Zugspitze, $\mathrm{KM}=$ Karwendel mountains, $\mathrm{MM}=$ Mieming mountains and $\mathrm{WM}=$ Wetterstein mountains. $\mathrm{BNF}=$ Brenner normal fault, ISZ $=$ Inntal shear zone 
Fig. 3 Conceptual cross sections of the NCA. Cretaceous synorogenic sediments color-coded for type (UFD = upper footwall deposits; TSTD $=$ thrust-sheet-top deposits) and age. a Zugspitze section using the existing tectonic subdivision. Geometry of Wetterstein Mountains taken from Schneider (1962). Z=Zugspitze thrust, $\mathrm{M}=$ Mieming thrust. $\mathbf{b}$ Section west of the study area simplified from Eisbacher et al. (1990)

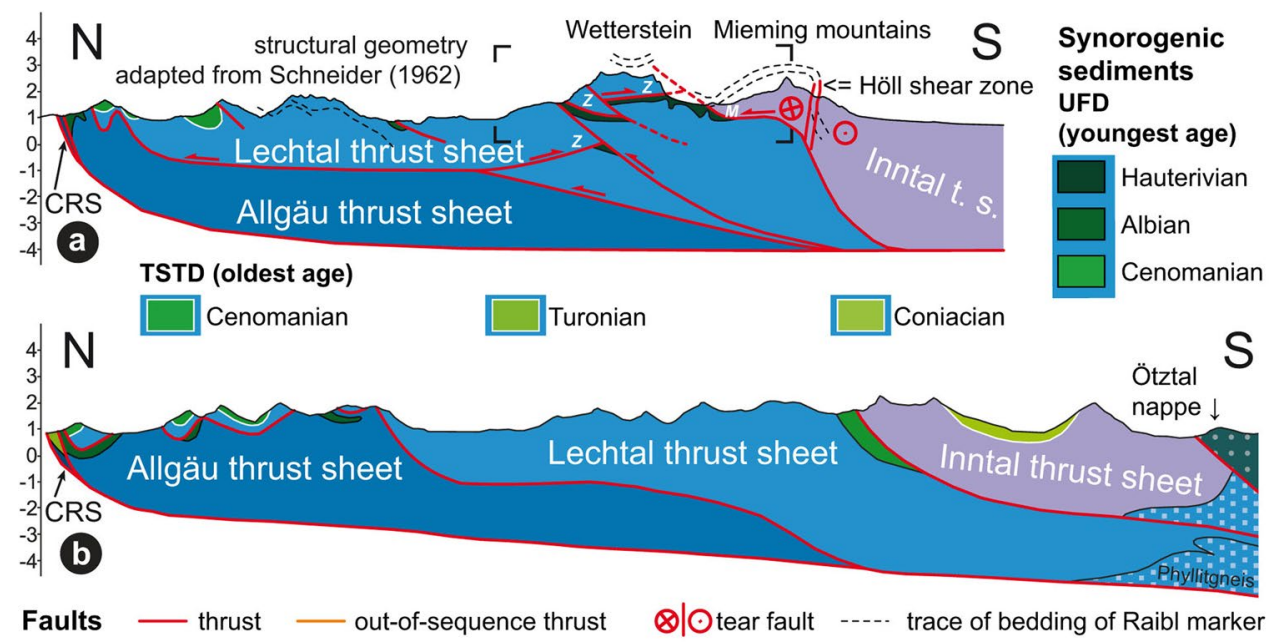

the Inntal- and Krabachjoch thrust sheets is similar to the underlying Lechtal thrust sheet, these have been regarded to be part of the Tirolic nappe system, while the CRS, the Lechtal- and Allgäu thrust sheets have been interpreted as a part of the Bajuvaric nappe system (Hahn 1913a; Tollmann 1976b).

One of the key problems that the early mappers encountered was the structural ambiguity in the Karwendel, Wetterstein and Mieming mountains in Bavaria and Tirol (see Fig. 2 for location). As a consequence, a long-lasting controversy regarding the existence or non-existence of the Inntal thrust sheet developed. One group of researchers insisted on the structural continuity between Lechtal and Inntal thrust sheets that both emplace Triassic carbonates onto Cretaceous marls, and rejected the existence of an Inntal thrust sheet (Fig. 3a). Another group emphasized the stratigraphic connection of the Wetterstein mountains with their northeastern foreland (Fig. 2), and thus separated Lechtal and Inntal thrust sheets (Fig. 3a) (see Schneider 1962 and "The controversy").

Based on the structural analysis of macro- and mesostructures in the Mieming and Wetterstein mountains, we show in this contribution that the observations of both groups of researchers were correct. The problem can be solved when the old-on-young criterion for the emplacement of thrust sheets is strictly followed, and thus young-on-old contacts with reverse kinematics that are observed locally at the base of the Inntal thrust sheet, are considered to be out-ofsequence thrusts. If out-of-sequence thrusts have not enough offset, they cannot be used for the separation of major tectonic units, as they often terminate laterally, and dissect thrust sheets that already exist. As a consequence, the thrust sheets need to be reorganized, and we propose a new tectonic subdivision of the western NCA, following an earlier publication on this subject by Kilian and Ortner (2019). We discard the names used by Ampferer (1912) and introduce new names to define thrust sheets that are entirely floored by synorogenic sediments on top of the tectonically deeper unit. Doing this, we connect thrust sheets being part of different thrust systems, and the thrust systems of the western NCA have to be redefined as well.

\section{Sedimentary succession}

The Permo-Triassic part of the sedimentary succession building the western NCA thrust sheets was deposited on the SE passive margin of Pangea located west and north of the westward closing end of the Neotethys ocean (Fig. 1b) (e.g., Lein 1987; Haas et al. 1995). We use names of stratigraphic units according to the Austrian stratigraphic chart (Piller et al. 2004) The succession starts with Permian continental clastics (Alpine Verrucano) (Stingl 1982, 1984), interfingering with salt-bearing evaporites and shales (Haselgebirge) (Spötl 1988, 1989; Leitner and Spötl 2017), followed by Lower Triassic evaporites and dolomites of the Reichenhall Formation (e.g., Schenk 1967). Haselgebirge and Reichenhall Formation form the basal décollement of the NCA (Linzer et al. 1995; Eisbacher and Brandner 1996). The Haselgebirge salt has important consequences for the geometry and thicknesses of the younger deposits, and salt tectonics have only recently been recognized in the NCA (Granado et al. 2018; Fernández et al. 2020; Strauss et al. 2021). Well bedded limestones of the Virgloria and Steinalm Formations are the first basinal and carbonate ramp deposits of the area (Bechstädt and Mostler 1976), and form, together with the Reifling Formation, the Alpine Muschelkalk Group (Bechstädt and Mostler 1974). Breakup of the Steinalm ramp caused facies heteropy in the Middle Triassic, when the basinal Reifling Formation interfingered with the Wetterstein limestone (Bechstädt and Mostler 1976), the latter representing the first major carbonate platform of the NCA, more than $1400 \mathrm{~m}$ thick at Zugspitze ( $\mathrm{Z}$ of Fig. 2; Ortner 2015) and in 
the Mieming mountains (MM of Fig. 2; Miller 1965). In the Ladinian to Carnian, the younger part of the Wetterstein platform interfingers with the marly Partnach beds. Later in the Carnian, the mixed carbonatic-siliziclastic succession of the Raibl beds ends growth of the Wetterstein platform, and covers the platforms and interplatform basins (Brandner 1984). A new carbonate platform develops in the Norian, and the more than $1000 \mathrm{~m}$ thick Hauptdolomit is deposited (Fruth and Scherreiks 1982, 1984). Toward the end of the Norian, this platform started to break apart, and the basins of the Kössen Formation developed in the Rhätian that interfinger with another platform, the Upper Rhätian limestone (Golebiowski 1991).

The Jurassic sedimentary succession of the NCA is controlled by rifting and opening of the Piemont-Liguria ocean that separated the African continent and the Adriatic microcontinent from Europe (Froitzheim and Manatschal 1996; Manatschal 2004). The syn-rift succession in the studied part of the NCA includes red nodular limestones of the Adnet Formation that accumulated on deep, submarine highs and are meters to tens of meters thick, and the basinal Allgäu Formation with spiculitic, siliceous limestones and occasional breccias and olistoliths (Jacobshagen 1965; Bischof et al. 2010), with thicknesses of hundreds of meters. After breakup in the Late Jurassic, the Ruhpolding radiolarite and the pelagic limestones of the Ammergau Formation accumulated, the latter reaching into the Early Cretaceous (Miller 1963c).

Synorogenic sedimentation started diachronously in the Early Cretaceous, with deposition of the marly Schrambach Formation that contains quartz-bearing calcarenites in its youngest part. According to Vidal (1953) and Miller (1963c) it reaches from the Berriasian at least into the Hauterivian. No younger deposits are known in the study area, but basanitic volcanic dykes and sills are found within the Jurassic-Cretaceous units between the Wetterstein and Mieming mountains that have been given the local name Ehrwaldites (Pichler 1866). These volcanites have been radiometrically dated at $100 \mathrm{Ma}(99.4 \pm 2$; Albian-Cenomanian boundary; Trommsdorff et al. 1990).

\section{Structural evolution of the NCA}

In the Late Jurassic, Neotethys ophiolites were obducted onto the passive margin of the NCA (Gawlick et al. 1999; Schmid et al. 2004). These ophiolites are not exposed in the NCA, however, reworked ophiolitic detritus is widespread in Cretaceous synorogenic formations and has been related to Cretaceous erosion of the ophiolites (e.g., Pober and Faupl 1988; Schuster et al. 2007; Stern and Wagreich 2013). The obduction event was associated with imbrication and uplift of the distal continental margin, gravitative mobilization of units and emplacement of swarms of slides onto the more internal continental margin (Tollmann 1987; Mandl 2000; Frisch and Gawlick 2003). This sliding established the original superposition of the Lower Juvavic units onto the Tirolic nappe system, even if parts of the Juvavic nappe system were displaced in the Lower Cretaceous (see below; Mandl 2000). No direct evidence of these Jurassic processes has been documented in the western NCA.

Nappe stacking in the NCA of western Austria and southern Germany is closely related to Cretaceous syntectonic sedimentation. Inversion of the continental margin took place during Cretaceous intracontinental subduction within the Adriatic plate (Janák et al. 2004; Stüwe and Schuster 2010). Shortening caused NW-directed stacking of thrust sheets in the NCA, involving tens of kilometers of shortening (Eisbacher et al. 1990; Linzer et al. 1995; Eisbacher and Brandner 1996). The age of syntectonic sediments below a thrust sheet allows to define a maximum age of emplacement, while synorogenic clastics unconformably overlying the exhumed thrust sheet give a minimum age (upperfootwall deposits and thrust-sheet-top deposits of Ortner 2003a; Ortner and Gaupp 2007; Ortner 2016; see Figs. 2, $4 a, b)$. The ages of upper-footwall deposits suggest thrust sheet emplacement between the Hauterivian and Turonian. Unfortunately, these ages were not known or not considered at the time when the thrust sheets were defined, and several thrust sheets rest on sediments of different age (numbers with references indicate locations of Fig. 2, color coding in Fig. $4 \mathrm{c}$ gives thrust age).

The western tip of the Inntal thrust sheet overlies Cenomanian shales and sandstones (Lech Formation; 1-Huckriede 1958; 2-Helmcke and Pflaumann 1971; 3-Leiss 1988), while the Inntal thrust sheet of the Mieming and Karwendel mountains rests on Hauterivian shales and sandstones (Schrambach Formation; 4Miller 1963c; Morlok 1987). The eastern tip of the Inntal thrust sheet overlies Turonian-Coniacian thrust-sheet-top deposits of the Gosau Group (15-Sanders 1996).

The Lechtal thrust sheet of the Wetterstein mountains overlies Hauterivian shales and sandstones (Schrambach Formation; 5-Vidal 1953). However, at the northern margin of the NCA the Lechtal thrust sheet overthrusts Albian shales and sandstones (Losenstein Formation; 6-Zacher 1966; 9-Höfle et al. 1969; 7-Risch 1971; 8-Gaupp 1982). Cenomanian thrust sheet-top deposits unconformably overlie the external Lechtal thrust sheet (Branderfleck Formation; 10-Gaupp 1982; Weidich 1984). West of the Arlberg, the Lechtal thrust sheet is emplaced onto Turonian-Coniacian (12Schidlowski 1962; Winkler 1988) or even Coniacian-Santonian (12-Leiss 1992) shales and conglomerates of the Lech Formation. East of the Inn valley, it overlies Turonian deposits (Branderfleck Formation; 14-Zeil 1955; Ganss 1967; Doben 1970). 
Fig. 4 Sketches (a) and (b) illustrate thrust sheet emplacement and syntectonic sedimentation using a ramp-flat model, following an idea of Ortner (2003a) and Ortner and Gaupp (2007). Sketch is based on the cross section of Fig. 3b. Thickness of preorogenic deposits is downsized, thickness of synorogenic deposits exaggerated. a Emplacement of a thrust sheets onto upper-footwall deposits on a hanging wall flat during Albian-Cenomanian. The youngest sediments below a thrust sheet indicate the time when a thrust sheet ends deposition as it covers the sea floor. In transport direction these ages get younger, as the thrust sheet moves across the hanging wall flat. b Folding of thrust sheets following thrust transport between Turonian and Maastrichtian. c Age of thrust contacts in the western NCA based on synorogenic sediments according to the model of (a) and (b). The Allgäu, Lechtal, and Inntal thrusts are the thrusts at the base of the respective thrust sheets
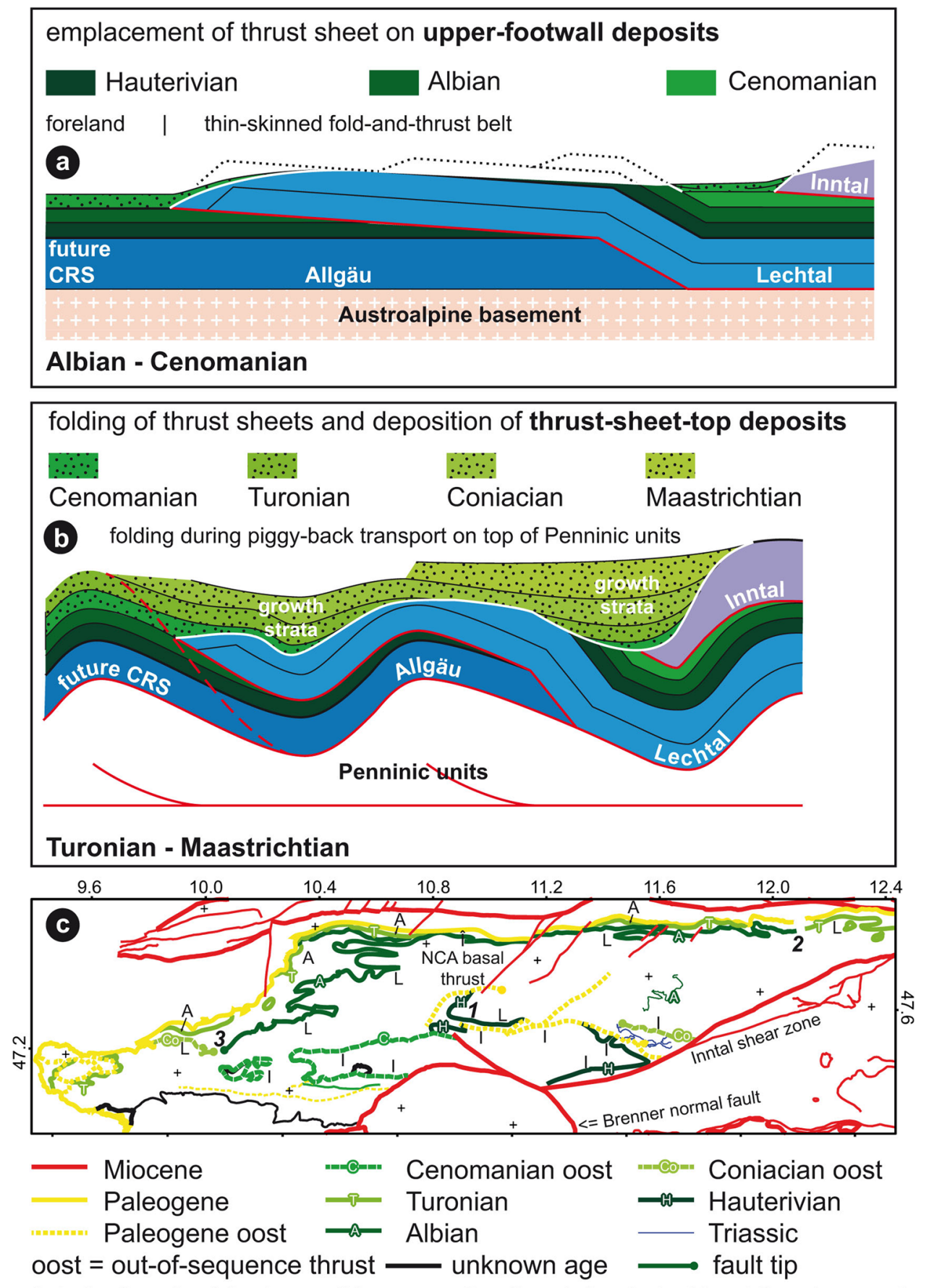

$A, L, I=$ thrusts at the base of the respective thrust sheets (not local thrust names)

$A=$ Allgäu thrust $\quad L=$ Lechtal thrust $\quad I=$ Inntal thrust
In the $C R S$, upper-footwall deposits and thrust-sheet-top deposits are found in one continuous sedimentary succession (11-Gaupp 1982; 13-Doben 1985). Therefore, the position of the northern tip of the Lechtal thrust sheet in the Cenomanian was south of the CRS, which was, at that time, also the northern, external tip of the thrust belt at the transition to a foreland basin (Fig. 4a) (Gaupp 1983;
Sieberer and Ortner 2018). The Allgäu thrust sheet was emplaced onto Turonian thrust-sheet-top deposits of the CRS (Branderfleck Formation; 11-Gaupp 1982; Weidich 1984; 13-Doben 1985).

Thrust sheet emplacement was generally not accompanied by major folding. From the Cenomanian-Turonian onward, when the external NCA had lost their crystalline 
basement (e.g., Oberhauser 1995; Faupl and Wagreich 2000; Handy et al. 2010) and subduction of the Piemont-Liguria ocean had begun, the NCA travelled across the tectonically deeper Penninic units (Frisch 1979; Winkler 1988; Froitzheim et al. 1996; von Eynatten and Gaupp 1999). The major thrusts were folded (the "Deckenfaltung" = refolding of nappes of Kockel 1926), which is recorded in the growth strata of the thrust-sheet-top deposits (Branderfleck Formation and Gosau Group; Ortner 2001, 2007; Ortner and Gaupp 2007; Sommer et al. 2010; Ortner et al. 2016; Sieberer 2020; Fig. 4b). This shortening persisted into the Paleogene and progressively changed toward a N- and NNE direction in the Paleogene (Eisbacher and Brandner 1996), culminating in Late Eocene collision (e.g., Handy et al. 2010). This observation is in contrast to the tectonic evolution of the Austroalpine basement units, where Late Cretaceous stretching separates Cretaceous and Cenozoic shortening (Froitzheim et al. 1994; Neubauer et al. 1995; Fügenschuh et al. 2000). This event has not been observed in any of the more recent studies on the tectonic development of the
NCA (May and Eisbacher 1999; Auer and Eisbacher 2003; Tanner et al. 2003; Behrmann and Tanner 2006; Kilian and Ortner 2019; Oswald et al. 2019; Kilian et al. 2021), except Froitzheim et al. (2012). During the Miocene, renewed NNE- to NE-directed shortening affected the NCA (Decker et al. 1994; Ortner 2003b) that was largely related to activity of strike-slip faults and contemporanous to postcollisional transport of the Alpine wedge into the Cenozoic foreland basin on the European margin (Ortner et al. 2015; Schuller et al. 2015).

\section{The controversy}

The separation of the Inntal from the Lechtal thrust sheet was controversially discussed ever since the Inntal thrust sheet was defined by Ampferer (1912) both in the Karwendel mountains (see Kilian and Ortner 2019) and the Wetterstein and Mieming mountains (see Fig. 2) discussed here. Both the Wetterstein and Mieming mountains are built by the kmthick Wetterstein limestone and the underlying Muschelkalk

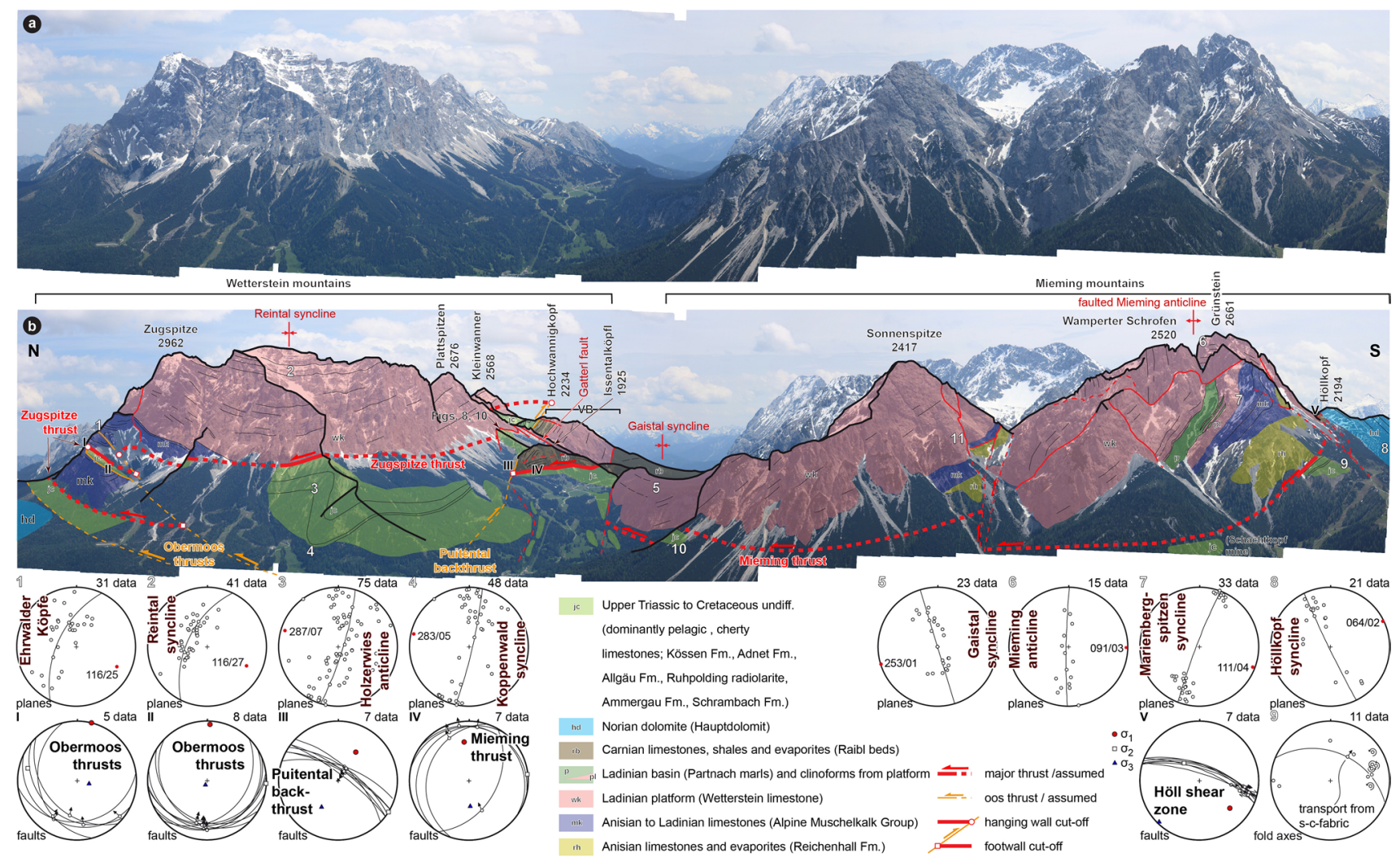

Fig. 5 a View of the Wetterstein and Mieming mountains from the west, and $\mathbf{b}$ geologic interpretation. Stereograms 1-8: analysis of bedding orientations in lower hemisphere stereographic projections and calculated fold axes. The respective white numbers in (b) indicate, where the data were collected. Stereograms I-V: mesofaults measured at major fault contacts in lower hemisphere stereographic projections, and mean transport direction $\left(\sigma_{1}\right)$ calculated from the fault data set using the NDA method (Spang 1972) as implemented by Ortner et al. (2002). Note that data of V were collected at the eastern side of the mountain, behind the ridge shown. Data in diagram III from Kreidl (2015), data in diagram 9 from van Kooten (2016). All stereograms of this paper were created using the TectonicVB software (Ortner et al. 2002). Numbers 9-11 indicate locations mentioned in the text. $\mathrm{VB}=$ Vorbergzug 
Group, often floored by the evaporitic Reichenhall Formation. These Triassic rocks are emplaced onto Cretaceous marls of the Schrambach Formation (Fig. 5). One group argued that there is a continuous sedimentary succession connecting the northeastern foothills of the Wetterstein mountains (Fig. 2), which are clearly part of the Lechtal thrust sheet, with the Wetterstein mountains (Ampferer 1912, 1914a, 1931, 1942; Leuchs 1924, 1935; Beurlen 1944; Vidal 1953; Bögel 1960; Ferreiro Mählmann and Morlok 1992). According to this interpretation, major south-directed backthrusting within the Lechtal thrust sheet is required (Fig. 3a) (Zugspitze thrust of Mylius 1916; Miller 1963a, b; Eisbacher and Brandner 1995). Another group connected the Mieming and Zugspitze thrusts (see Fig. 3a) and interpreted the Lechtal thrust sheet to be continuous with the Inntal thrust sheet (Schlagintweit 1912a, b; Richter 1929; Haber 1934; Kraus 1957; Rüffer and Bechstädt 1995). However, these authors could not separate this allochthon from its northern foreland, where a sedimentary succession linking the two units is observed.

\section{Kinematics of thrusts}

When the tectonic subdivision of the NCA was defined at the start of the twentieth century, thrust kinematics were not yet properly understood. For the authors defining the nappes of the western NCA, the only requirement was to have thrusts on all sides (e.g., Ampferer 1914b, p. 319, 324; Heißel 1958, p. 128; Tollmann 1973 , p. 8 ), and they used any thrust irrespective of its geometry or age. The latter two authors stated a thrust would more commonly emplace old on young rocks, but this was not considered to be mandatory. This led to a tectonic subdivision in which thrust sheets are bounded by thrusts of different age (compare Figs. 2, 4c).

It was only from the 1970s onward that key papers on the geometry and kinematics of thrusting were published (e.g., Elliott 1976; Boyer and Elliott 1982; Suppe 1983; Suppe and Medwedeff 1990) and these principles applied to the major thrusts of the western NCA (Eisbacher et al. 1990). It was known that thrusts have lateral terminations and grow laterally during foreland propagation while offset increases (Fig. 6a) (Elliott 1976). Thrusts will therefore cover (i) younger sediments in the direction of frontal and (ii) lateral propagation (Fig. 6b) (e.g., Davis et al. 2005; Mazzoli et al. 2005; Bergen and Shaw 2010). Lateral propagation of thrusts (iii) can cause neighbouring thrusts to merge that may have initiated at different times (Fig. 6c).

All these cases are observed within the western NCA: (i) The Lechtal thrust has an Albian age over much of its length but has a Hauterivian age where it reappears in a more internal position below the Zugspitze (1 of Fig. 4c).

(ii) Its easternmost part has a Turonian age ( 2 of Fig. 4 c).

(iii) The Albian Lechtal thrust has its western tip NNE of

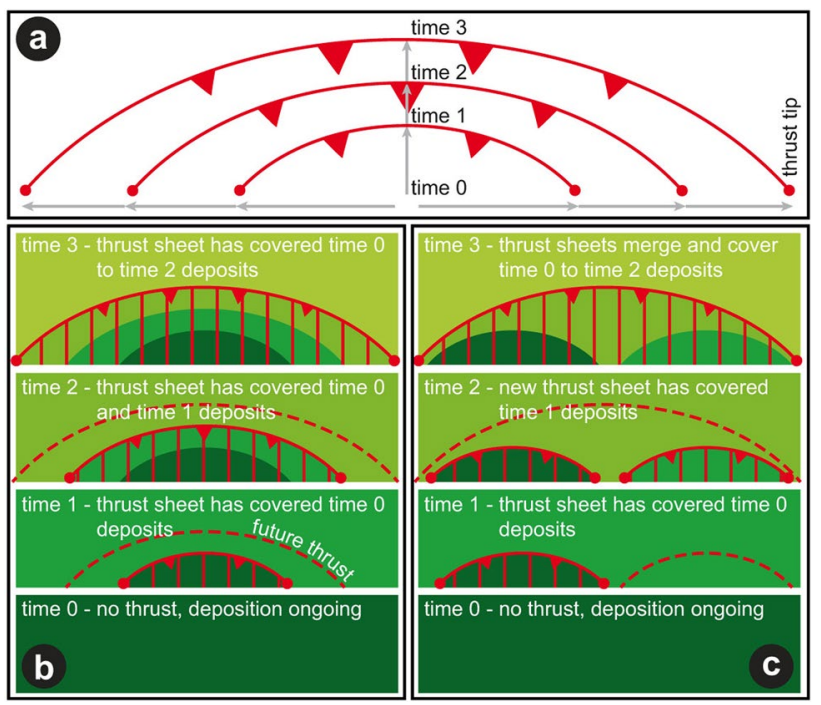

Fig. 6 Sketches illustrating the temporal development of thrusts on a hangingwall flat in map view. a Foreland- and lateral propagation of a thrust in three steps. b Thrust propagation and syntectonic sedimentation. c Lateral coalescence of thrusts and syntectonic sedimentation. In $\mathbf{b}$ and $\mathbf{c}$ red hatched area represents thrust sheet. In background the age of sediments covered by thrust sheet is shown. Red dashed line indicates position of thrust in the next stage of thrust propagation

Lech, where stratigraphic offset disappears (Figs. 2, 3 of Fig. 4c). Further west, a thrust of Coniacian age has its eastern tip. This observation shows that the Lechtal and underlying Allgäu thrust sheets are not completely separated (as already stated by Spengler 1953, p. 53; Richter 1956, p. 190; Hückel et al. 1961, plate 5; Trümpy 1969, p. 108). However, the Albian and the Coniacian thrusts have traditionally been connected (Ampferer 1914b; Tollmann 1970b).

We term thrusted units that are not completely separated from their footwall thrust sheets, and far-travelled allochthons nappes. In the NCA, only the units of the Juvavic nappe system are entirely separated, while the thrusts between units of the Bajuvaric and Tirolic nappe system tend to end laterally (e.g., 1 of Fig. 1a).

Thrusts in thrust belts typically propagate toward the foreland and downward (Boyer and Elliott 1982; Butler 1987; Morley 1988; Verges and Muñoz 1990). This is also the case within the western NCA, where the oldest, Hauterivian thrust transport is that of the uppermost large thrust sheet, and the youngest, Paleogene thrust is that of the lowermost thrust sheet onto Penninic units (Fig. 4c) (Mandl 2000; Ortner 2003a). We use the term out-of-sequence thrust for those faults that are outside this foreland-propagating sequence, and that often cut across older thrusts (compare Morley 1988; Verges and Muñoz 1990; McClay 1992).

Geometry might be complex when thrust boundaries get folded as new thrusts form in the footwall of an existing thrust during in-sequence thrust propagation. Folded thrusts 
are likely places where out-of-sequence thrusts form when shortening persists (e.g., Gilluly 1960; Boyer 1992).

\section{Results}

Here we present the results of our structural investigation in the Mieming and Wetterstein mountains, based on the relative succession and cross-cutting relationships of structures. Section "Western and southern flank of the Wetterstein and Mieming mountains" establishes the regional nature of the Zugspitze and Mieming thrusts and its kinematics. Section "The zone of Upper Triassic to Lower Cretaceous rocks S of the Wetterstein mountains (Puitental Zone)" adds the timing of the Zugspitze thrust relative to E-trending strike-slip faults intruded by basanitic dykes and defines the Puitental Zone as a zone of backthrusting. Section "Mieming mountains and Vorbergzug" introduces the geology of the Mieming mountains and of the Höll shear zone as an important discontinuity. Section "Northern flank of the Wetterstein mountains" describes duplexing at the NW corner of Zugspitze. The duplex terminates against the Ehrwald branch of the Loisach fault in the West and passes into a zone of tight folding NW of Mittenwald where the Wetterstein carbonate platform interfingers with and is replaced by basinal marls.

\section{Western and southern flank of the Wetterstein and Mieming mountains}

The most prominent structures in the investigated area are the Mieming and Zugspitze thrusts (Fig. 5) that emplace Triassic carbonates onto marls of the synorogenic Schrambach Formation reaching into the Hauterivian (see "Sedimentary succession"). At outcrop scale, this thrust is parallel to bedding in the footwall (labels 3 and 9 of Fig. 5) in most places, but oblique to bedding in the hanging wall. The thrusts are associated with a shear zone with a thickness of several tens of meters, reaching downsection to the Kössen Formation, but not affecting the underlying competent Hauptdolomit. The thrusts are not continuously exposed, but well visible along the complete length of the western face of the Zugspitze (Fig. 5). Toward the E, numerous outcrops below the southern cliffs of the Wetterstein mountains (Leuchs 1930) indicate the regional nature of this contact (Fig. 5).

In an outcrop in the SE Mieming mountains at Marienbergjoch south of Ehrwald (label 9 of Fig. 5, Fig. 7b) top NW movements were recorded by NW-facing mesofolds in pelagic limestones of the Ammergau Formation, whereas the less competent, marly Allgäu and Schrambach Formations are deformed by NNE-facing mesofolds and s-c-fabrics (diagram 9 of Fig. 5) (van Kooten 2016). Isolated outcrops of the Jurassic-Cretaceous succession at the northwestern side of the Mieming mountains (label 10 of Fig. 5), and in mining galleries reaching from Schachtkopf under the western Mieming mountains (Schachtkopf mine of Fig. 5) (Ampferer and Ohnesorge 1924; Mutschlechner 1955) demonstrate the continuity of the Mieming thrust at the base of the Mieming mountains. The contact is seen to cut upsection continuously from the Reichenhall Formation in the South (above label 9 of Fig. 5) to the Raibl beds in the North (label IV of Fig. 5) at a rather constant angle of ca. $10^{\circ}$ in the Mieming mountains. In the Wetterstein mountains, the thrust cuts from the Wetterstein limestone downsection into the Muschelkalk Group toward the North, and also to the East, giving the impression of a syncline truncated at the base with a maximum stratigraphic reduction above label 3 of Fig. 5.

The sedimentary succession in the footwall of the thrust below the western wall of the Zugspitze and the Mieming mountains is exposed from the Schrambach Formation down to the Kössen Formation (Fig. 5). At the SW corner of the Zugspitze, the succession is deformed into the hectometric, overturned, SSW-facing Holzerwies anticline (label 3 of Fig. 5). Adjacent to the south follows the symmetric, tight to isoclinal Koppenwald syncline with a vertical axial plane (label 4 of Fig. 5).

S-C structures, dm-scale vergent folds and brittle faults within the shear zone below the main thrust consistently show NW- to NE-directed transport of the hanging wall (Fig. 7). In a key outcrop below the Plattspitzen south face (Fig. 8; see Fig. 5 for location), dm-scale folds (Fig. 8c, g, f), s-c-fabrics (Fig. 8, label 2 of subfigure f) and the relationship between the main thrust and foliation in the underlying incompetent units (Fig. 8g, e) indicate NW-directed transport at the Zugspitze thrust.

\section{The zone of Upper Triassic to Lower Cretaceous rocks S of the Wetterstein mountains (Puitental Zone)}

The roughly E-W trending strip of Upper Triassic to Cretaceous rocks $\mathrm{S}$ of the cliffs of the Wetterstein mountains has been named the Puitental Zone (see Fig. 7a for location) by Tollmann (1976b). These cliffs are fault-controlled (Ampferer 1912; Leuchs 1930). Three sets of strike-slip faults can be observed: (1) a set of sinistral, E-trending faults (Puitental fault set), (2) a set of sinistral, NE-trending faults (Loisach fault set), and (3) a set of dextral, WNW-trending faults (Ammer fault set). The Loisach and Ammer fault sets are named following Kockel et al. (1931) and SchmidtThomé (1954). All of them offset the Zugspitze thrust in the area, and each other in the sequence described. Figures 9 and 10a give examples of the Puitental fault set: The 
Fig. 7 Tectonic map of the Mieming, Wetterstein, and eastern Karwendel mountains. See Fig. 2 for location. a Tectonic subdivision of the study area following Heißel (1958) and Tollmann (1970a, 1976b). Trace of axial planes of major folds indicated, and numbered $1-15$ from $\mathrm{S}$ to $\mathrm{N}$ : $1=$ Höllkopf syncline, $2=$ Gleierschtal syncline, $3=$ Mieming —Bettelwurf anticline, $4=$ Gaistal-Hinterautal syncline, $5=$ Lermoos syncline, $6=$ Ehrwald anticline, $7=$ Reintal syncline, $8=$ Zugspitze anticline, $9=$ Wetterstein-Karwendel syncline, $10=$ Heiterwangersee anticline, 11 = Wamberg anticline, $12=$ Katzenstein syncline, $13=$ Loisachtal anticline, $14=$ Plansee syncline, $15=$ Krottenkopf syncline. Names largely according to Tollmann (1976b). b New tectonic subdivision. $\mathrm{OOS}=$ outof-sequence. Tectonic transport directions of hanging wall of thrusts documented in Fig. 5, additional data south of Ehrwald taken from van Kooten (2016), east of Ehrwald from Zambanini (2014). Major faults: $\mathrm{H}=$ Höll shear zone, $\mathrm{O}=$ Obermoos thrusts, $\mathrm{T}=$ Telfs fault, $Z=Z$ ugspitze thrust. $\mathrm{KM}=$ Karwendel mountains, $\mathrm{MM}=$ Mieming mountains and $\mathrm{WM}=$ Wetterstein mountains. $\mathrm{KWT}=$ Karwendel thrust sheet

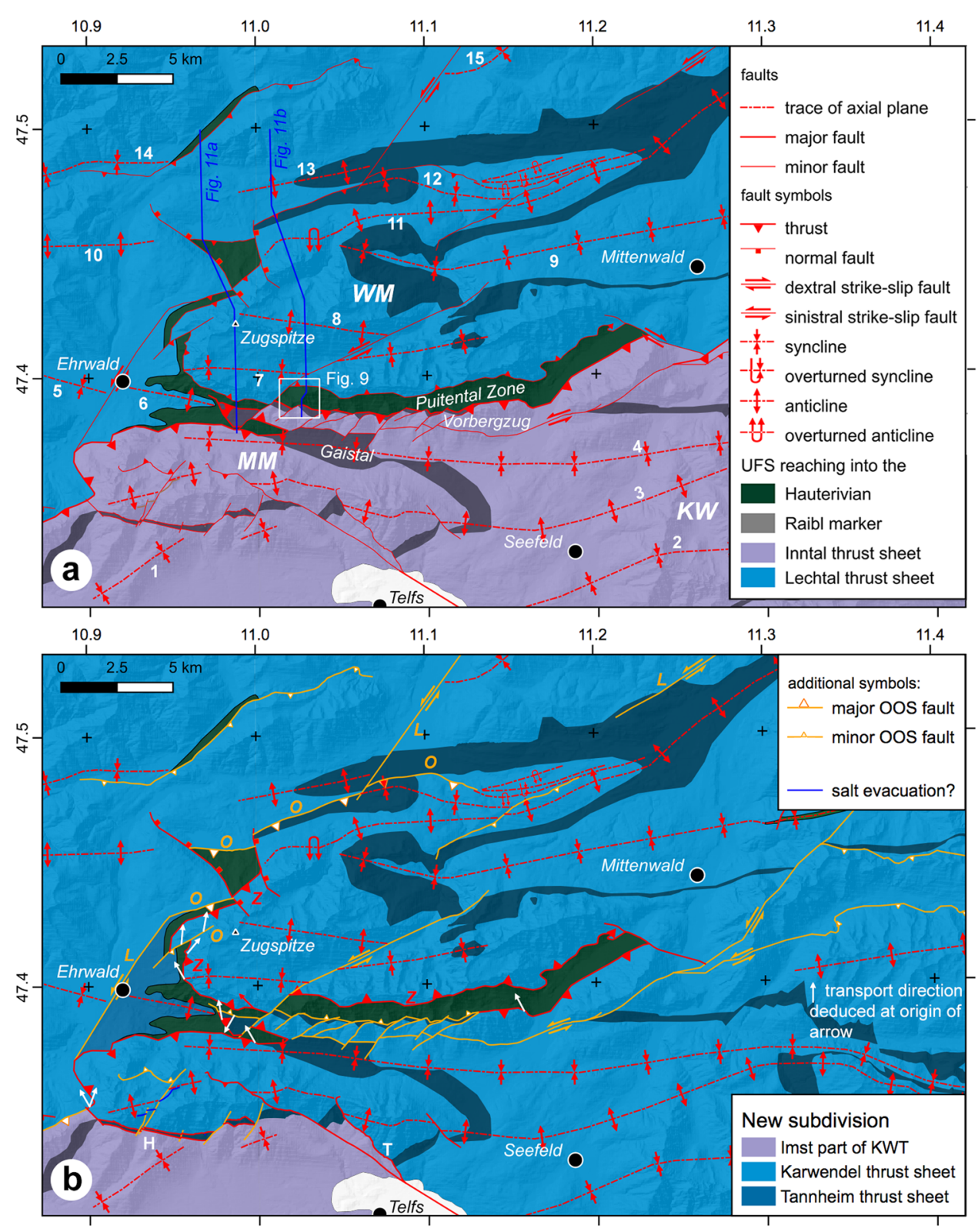

thrust is vertically uplifted on the southern side of a sinistral strike-slip fault (see also Fig. 9c), the sinistral kinematics indicated by s-c fabrics (Fig. 10c) within Lower Cretaceous marls of the Schrambach Fm. The shear zone is intruded by Ehrwaldite dykes (Fig. 10b) that are found both along the s- and c-planes of the shear zone. Most probably the shear zone existed already and provided the anisotropy used by the dykes, but the dykes are also deformed by the shear zone. Otherwise we would expect to find Ehrwaldite dykes also in a oblique orientation with respect to the shear zone, being sheared only locally.

In map view, the rocks of the Puitental Zone were also involved in the sinistral shearing across NE-trending faults at their southern margin, but this margin does not seem to be involved in the dextral faulting (see above). The northern tips of $600-800 \mathrm{~m}$ wide fault blocks separated by sinistral strike-slip faults reach into the zone of tight folds, but most sinistral faults disappear within the folded zone or are connected to the SSW-directed Puitental backthrust (III of Figs. 5, 7, 9a), except the Gatterl fault that has $1 \mathrm{~km}$ offset (Ferreiro Mählmann and Morlok 1992). Thus, sinistral strike-slip faulting across the Loisach fault set, backthrusting and folding were contemporaneous.

\section{Mieming mountains and Vorbergzug}

The backbone of the Mieming mountains is the Mieming anticline, a simple, $40^{\circ}$ E-plunging anticline $\mathrm{N}$ of Telfs (3 of Fig. 7a) (Mair 2020). Toward the West, the plunge diminishes to $25^{\circ}$ (Leo 2020), and then disappears in the western 

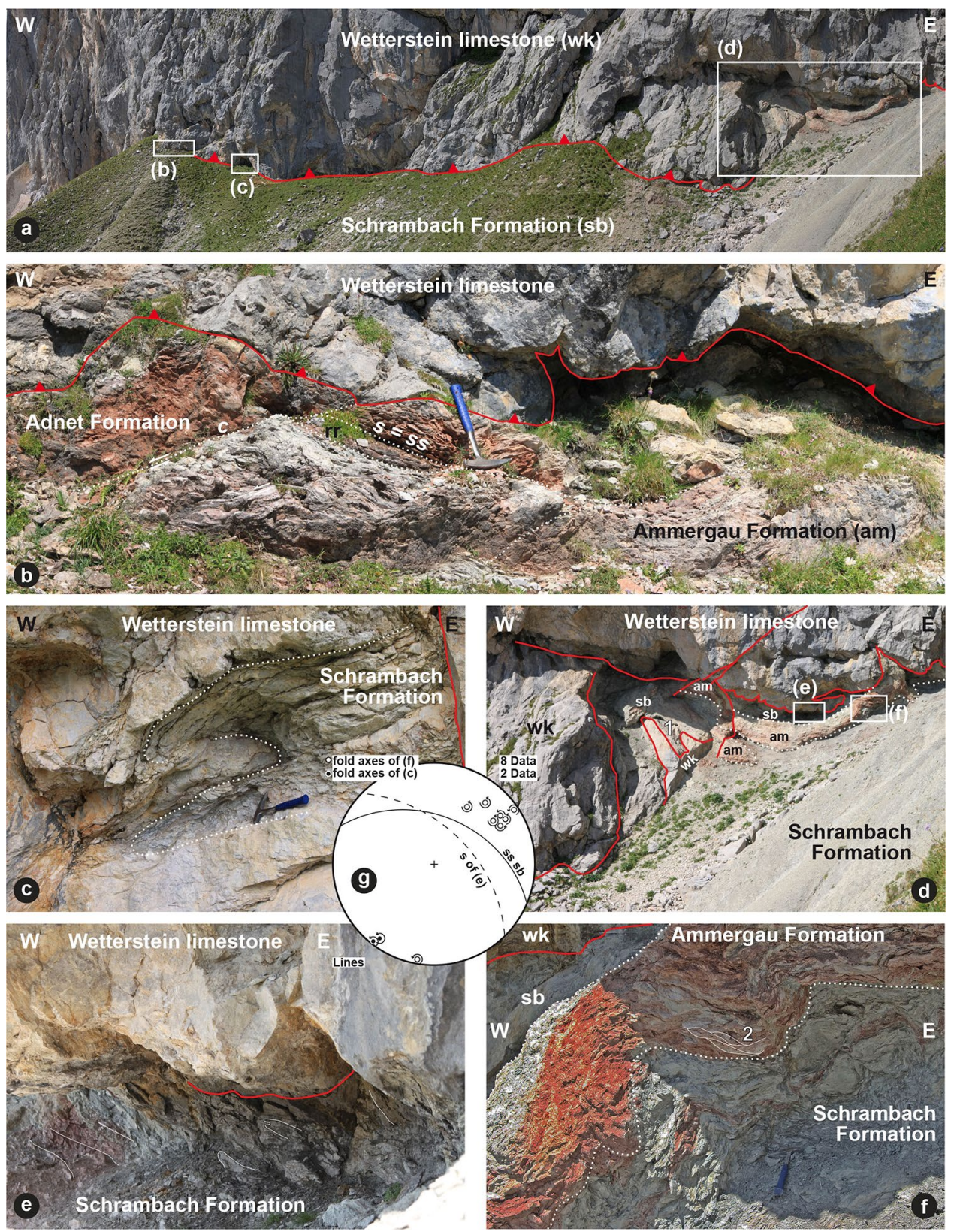

Fig. 8 Key outcrop of the thrust emplacing the Triassic onto the Lower Cretaceous Schrambach Formation at the base of the Plattspitzen south face at Angerbach (see Fig. 5 for location). a Overview of the outcrop giving the location of $\mathbf{b}, \mathbf{c}$ and $\mathbf{d}$. $\mathbf{b}$ Detail of the contact. An overturned slice with red limestones, Ruhpolding radiolarite and Ammergau Formation is observed below the Wetterstein limestone on top of the Schrambach Formation. Thickness of the succession is reduced as a result of pervasive shear band deformation. c Detail of the contact with isoclinal folding of the Schrambach Formation into the Wetterstein limestone. d Detail of the contact. Between the Wetterstein limestone and Schrambach Formation, an upright slice with red limestones of the Ammergau Formation and Schrambach Formation is intercalated that is isoclinally folded and sheared into the Wetterstein limestone. The overturned contact is refolded about fold axes subparallel to the outcrop surface, causing the complex boundary (label 1 of d). e Detail of d. A foliation within the Schrambach Formation is oblique to the contact against the Wetterstein limestone. Limbs of dm-scale isoclinal folds are parallel to the foliation. The intersection of bedding and foliation is subparallel to the majority of fold axes (see diagram g). $\mathbf{f}$ Detail of d. The Ammergau and Schrambach Formations are pervasively deformed into s-cfabrics that are refolded (label 2 of $\mathbf{f}$ ). Fold axes of $\mathrm{c}$ and $\mathrm{f}$ trend NE$\mathrm{SW}$, and verge to the NW (see diagram g). Note flame-like structures where the Schrambach Formation protrudes into the Wetterstein limestone in $\mathbf{b}, \mathbf{d}$ and $\mathbf{e}$ 


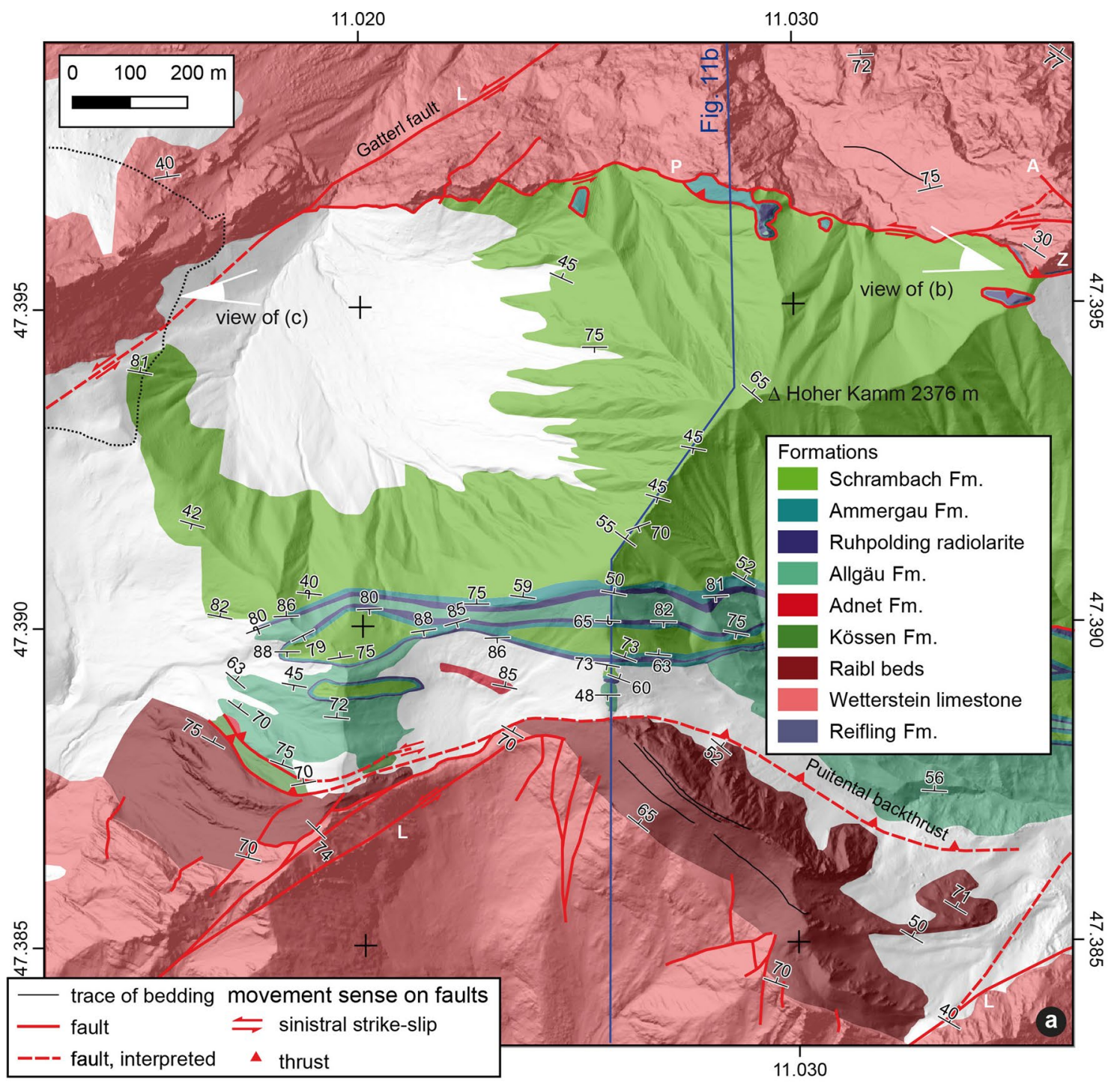

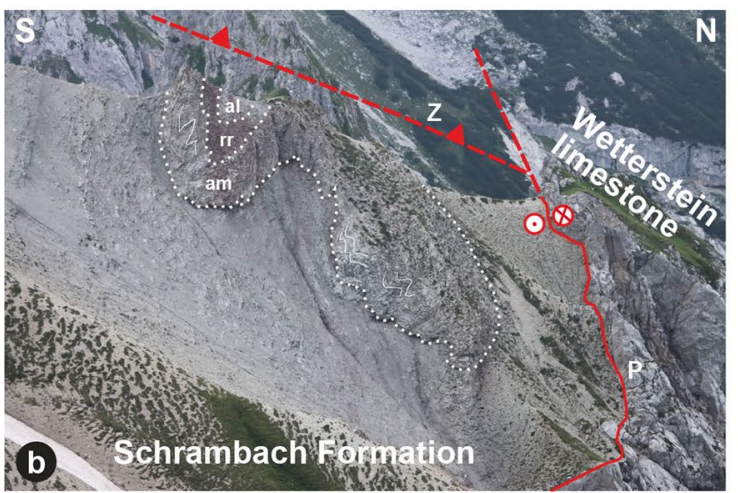

Fig. 9 a Geologic map of the Puitental Zone near Hoher Kamm, illustrating the deformation style at the southern margin of the Wetterstein massif (partly from Hildebrandt 2016). See Fig. 7a for location. b View to the west of the boundary between the Wetterstein limestone and the Schrambach Formation at Gatterl across a steep fault plane. Right below the contact, a thin, overturned slice with a succession of the Allgäu Formation, Ruhpolding radiolarite and Ammergau Formation marks the Zugspitze thrust (compare Fig. 8).

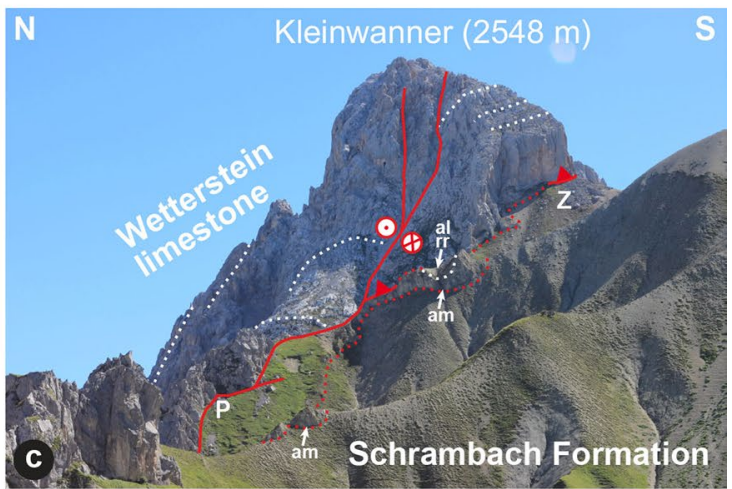

c View to the east to Kleinwanner. The overturned slice is seen right at the contact between Wetterstein limestone and Schrambach Formation in this perspective. Bedding within the Wetterstein limestone is folded in an anticline that is offset across vertical faults with sinistral offset together with the thrust contact. Abbreviations: am=Ammergau Fm., $r r=$ Ruhpolding radiolarite, al=Allgäu Fm; $A=A m m e r$ fault set, $\mathrm{L}=$ Loisach fault set, $\mathrm{P}=$ Puitental fault set, $\mathrm{Z}=$ Zugspitze thrust 


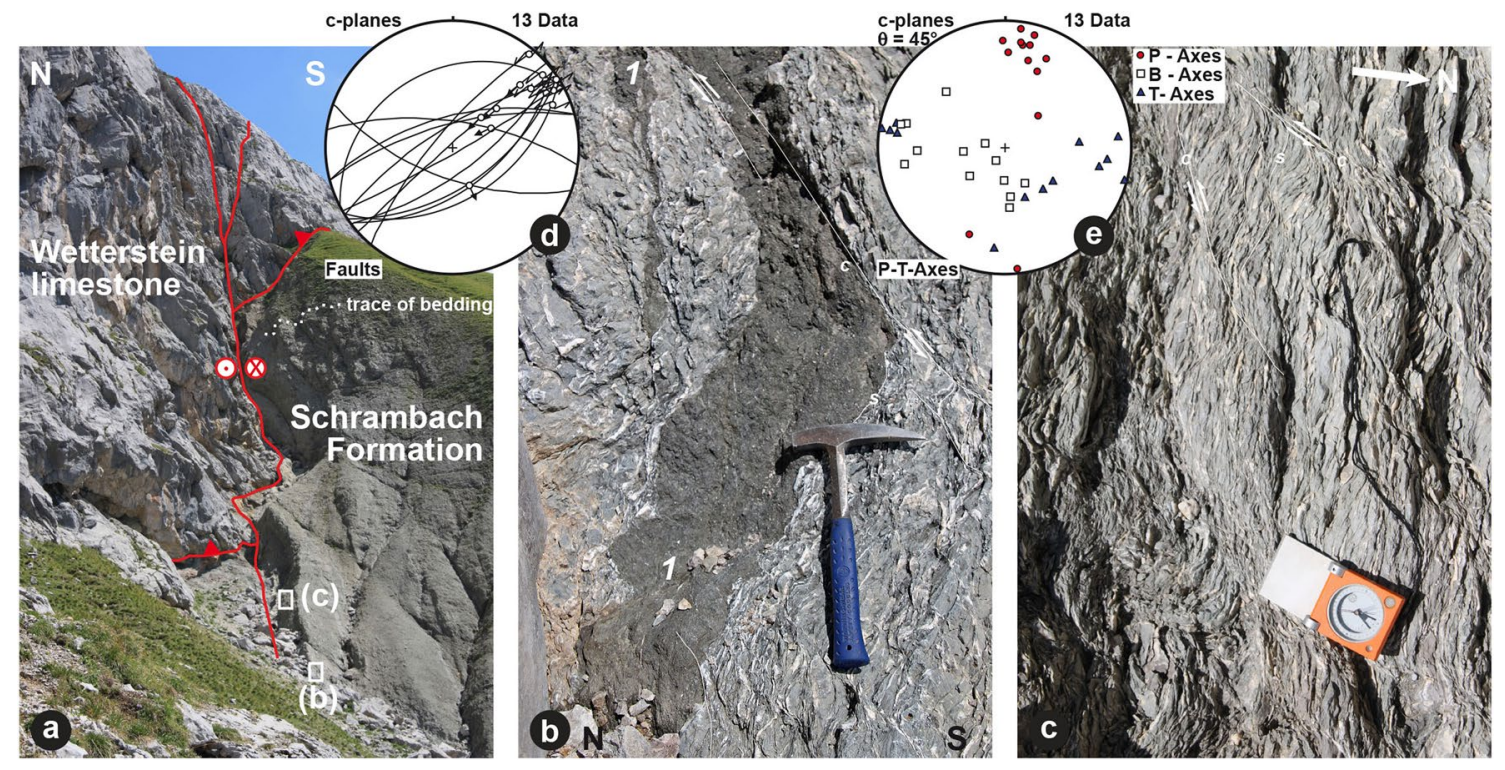

Fig. 10 a View to the East of the key outcrop of the Zugspitze thrust at Angerbach. The Zugspitze thrust is offset by a E-striking sinistral fault that deforms the Schrambach Formation pervasively (b, c). b Ehrwaldite dyke (label 1) within the Schrambach Formation. The dyke intruded both the s- and the c-planes of the shear zone, suggest- ing that the shear zone already existed. c S-C fabrics having shear band geometry within the Schrambach Formation seen from above. Sinistral offset is observed at the c-planes (diagram d), and the distribution of B- and T-axes along a girdle indicate transpressive sinistral shearing (diagram e; compare Meschede 1994)
Mieming mountains (diagram 6 of Fig. 5). Between Telfs and Ehrwald, the Mieming anticline has an axial plane dipping to the north (Becke 1983). The anticline is dissected by the NW-trending Telfs fault (T of Fig. 7b) that has a total offset of $5 \mathrm{~km}$ across its two branches. The western branch is connected to a steep oblique thrust that stacks the core of the anticline onto its northern limb (Miller 1963b; Becke 1983; Ferreiro Mählmann and Morlok 1992) and continues into its northern limb (label 11 of Fig. 5), but offset diminishes. Adjacent to the North is the open Gaistal-Hinterautal syncline (Fig. 5, 4 of Fig. 7a), and then the open anticline at Issentalköpfl (Figs. 5, 11a). This anticline disappears east of the Gatterl fault, only the northern limb of this anticline continues further to the East in the Vorbergzug (Figs. 5, 7a). Parts of the folds are cut out across E-trending faults that most probably belong to the sinistral Puitental fault set described in "The zone of Upper Triassic to Lower Cretaceous rocks S of the Wetterstein mountains (Puitental Zone)". Like the Puitental Zone, the Mieming mountains are also dissected by $800 \mathrm{~m}$ spaced NE-trending sinistral faults that delimit structurally different units.

Toward the South, the Wetterstein limestone of the Mieming mountains is bounded by a major dextral strike slip fault that follows the shales and carbonates of the Raibl beds (Höll shear zone; H of Fig. 7b; diagram V of Fig. 5). This is a major break in the structural architecture in this part of the NCA: South of the Höll shear zone fold axes are uniformly SW-NE oriented (e.g., diagram 8 of Fig. 5) and terminate against the fault (Fig. 7). Fold axes $\mathrm{N}$ of this zone are parallel to the fault (diagrams 1-4 of Fig. 5). This applies for the Karwendel mountains as well (traces of fold axial planes 2, 3, 4 of Fig. 7a; see also Heißel 1978; Kilian and Ortner 2019; Kilian et al. 2021). NW of Telfs, the Höll shear zone is truncated by the Telfs fault ( $\mathrm{T}$ of Fig. $7 \mathrm{~b}$ ) that also offsets the Mieming anticline and is part of the dextral Ammer fault set of "The zone of Upper Triassic to Lower Cretaceous rocks $\mathrm{S}$ of the Wetterstein mountains (Puitental Zone)". Folds are more variably WNW-ESE to WSW-ENE oriented (diagrams 5-7 of Fig. 5) S of Ehrwald (Fig. 7).

\section{Northern flank of the Wetterstein mountains}

At the northern side of the Wetterstein mountains, stratigraphy and structure change. The Wetterstein carbonate platform interfingers to the NE with basinal sediments of the Reifling and Partnach Formations with clinoforms seen in the north flank of Zugspitze and Waxenstein (Petschick 1983; Hornung and Haas 2017) and is entirely replaced by these basinal deposits in the Mittenwald area (Ampferer 1912; Mylius 1916; Jerz and Ulrich 1966). A tightly folded continuous sedimentary succession is present from the Partnach beds to the Hauptdolomit, and therefore the Wetterstein mountains are in stratigraphic contact with their northern foreland (see "Structural evolution of the NCA"; Fig. 11b).

Further to the west, the units of the Alpine Muschelkalk Group are exposed below the Wetterstein limestone cliffs in the western part of the north face of the Zugspitze. 


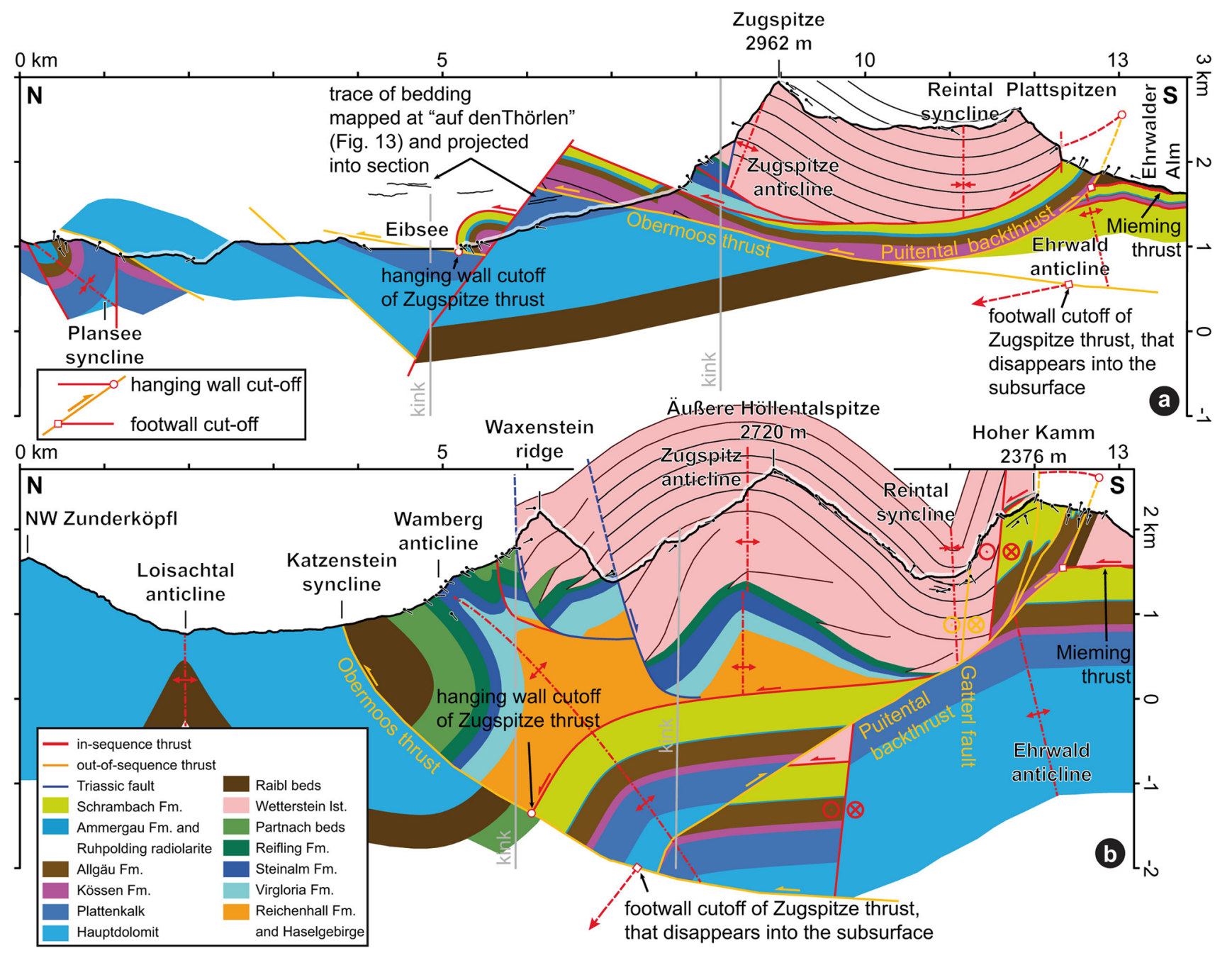

Fig. 11 Cross sections of the Wetterstein mountains. See Fig. 7a for location. a Section across the Zugspitze summit to Ehrwalder Alm. Note zone of Upper Triassic to Lower Cretaceous rocks below the Zugspitze (compare section 6/7 on plate 6 of Tollmann 1976b) terminating in an overturned position against upright Upper Triassic Plattenkalk at Eibsee, precluding a continuous sedimentary succession. The footwall cutoff related to the hanging wall cutoff of the Zugspitze thrust on top of this succession does not crop out, and has therefore been drawn schematically in the subsurface below the Plattspitzen. b
Section across the Waxenstein ridge to Hoher Kamm in the Puitental Zone. The space needed for downthrowing the Wetterstein platform against the basinal succession in the north has been interpreted to be related to salt tectonics in the Haselgebirge-Reichenhall succession that also facilitates tight recumbent folding of the Wamberg anticline, and folding of the Zugspitz anticline. Note that the Puitental backthrust was probably localized by the vertical step across a sinistral strike-slip fault

the floor thrust in Fig. 11a has $7 \mathrm{~km}$ offset. Summing up, shortening in the duplex is about $9 \mathrm{~km}$. Toward the east, the thickness and the number of slices of this duplex diminish (Fig. 12b).

The Jurassic succession associated with the floor thrust of the duplex is exposed at the SW shore of Eibsee (see Fig. 13 for location). An overturned succession of Schrambach to Kössen Fm., the latter in the core of a tight, recumbent fold, overlies the upright Hauptdolomit (Fig. 11a). An NNW-trending normal fault downthrows this succession to the Eibsee on its eastern side, but it is hidden below scree in the West. The Jurassic succession associated with the to be assumed. Slice 3 (Fig. 12a) is at least $800 \mathrm{~m}$ long, and 

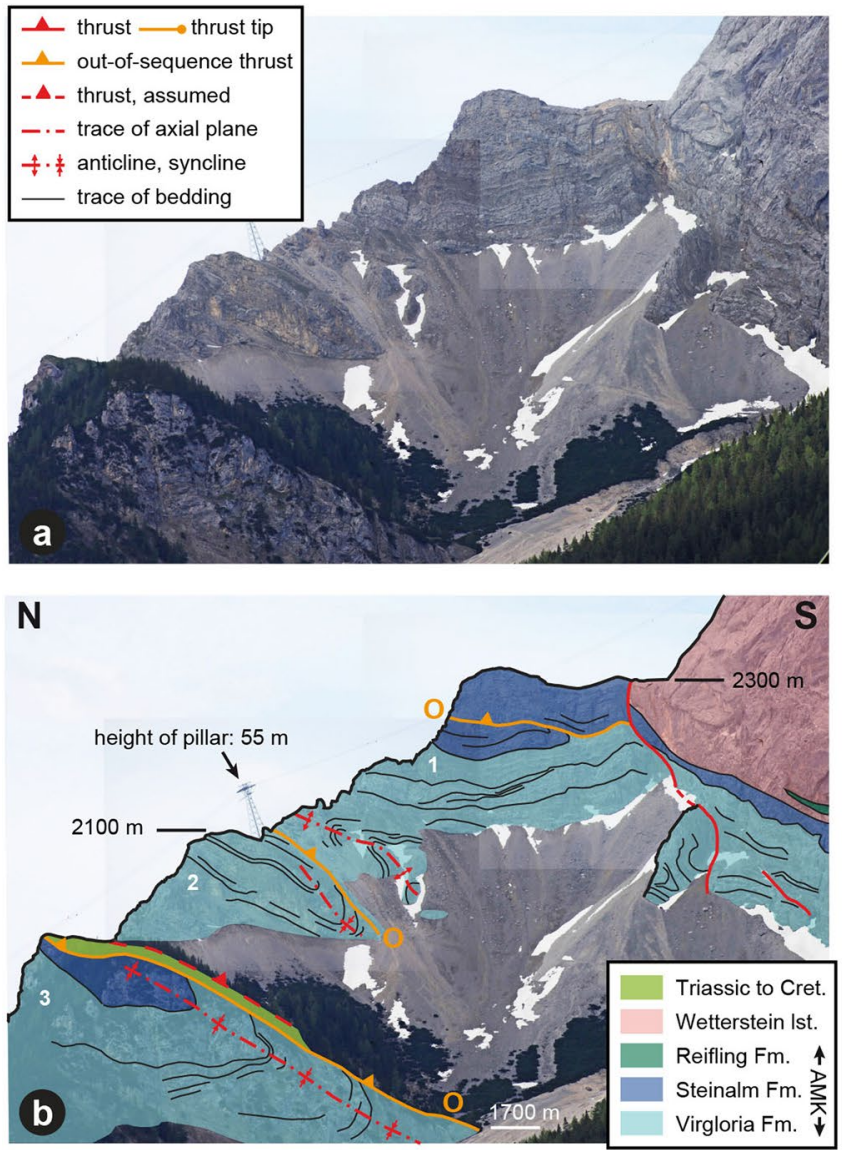

Fig. 12 Panoramic views of the NW edge of the Wetterstein mountains showing the Obermoos thrusts, labelled by $\mathrm{O}$. AMK = Alpine Muschelkalk Group. a Photograph and b interpretation of the Gamskar as seen from the West. Three slices of the Virgloria-Steinalm succession are stacked. In each slice an anticline is developed at the frontal end (see slice 1) and a syncline at the trailing end (seen in slices 2 and 3). Uppermost Triassic to Lower Cretaceous rocks are emplaced young-on-old on to slice 3 . Therefore, this thrust on top of slice three is out-of-sequence. $\mathbf{c}$ Photograph and $\mathbf{d}$ interpretation of

roof thrust is exposed in the northern Gamskar. A thin veneer of intensely sheared Jurassic rock (mostly Allgäu Formation) is found atop a thrust truncating the Virgloria and Steinalm Formations of the Alpine Muschelkalk (Fig. 12a, b). The thrust transports the hanging wall to the NNE (Fig. 5, diagrams I and II).

Figure 13 attempts a comprehensive view of the interdependent structures in 3D: In the northern foreland of the Wetterstein mountains, shortening increases significantly from $\mathrm{E}$ to $\mathrm{W}$ from a zone of tight folding in the NE, to a zone of duplexing at the NW side of the Zugspitze. Vertical uplift related to the $\mathrm{W}$-ward increase of shortening causes the $30^{\circ}$ eastward plunge of the folds above the duplex (e.g., Reintal syncline, Fig. 5, diagram 2) (Ortner 2015). This plunge is also associated with eastward
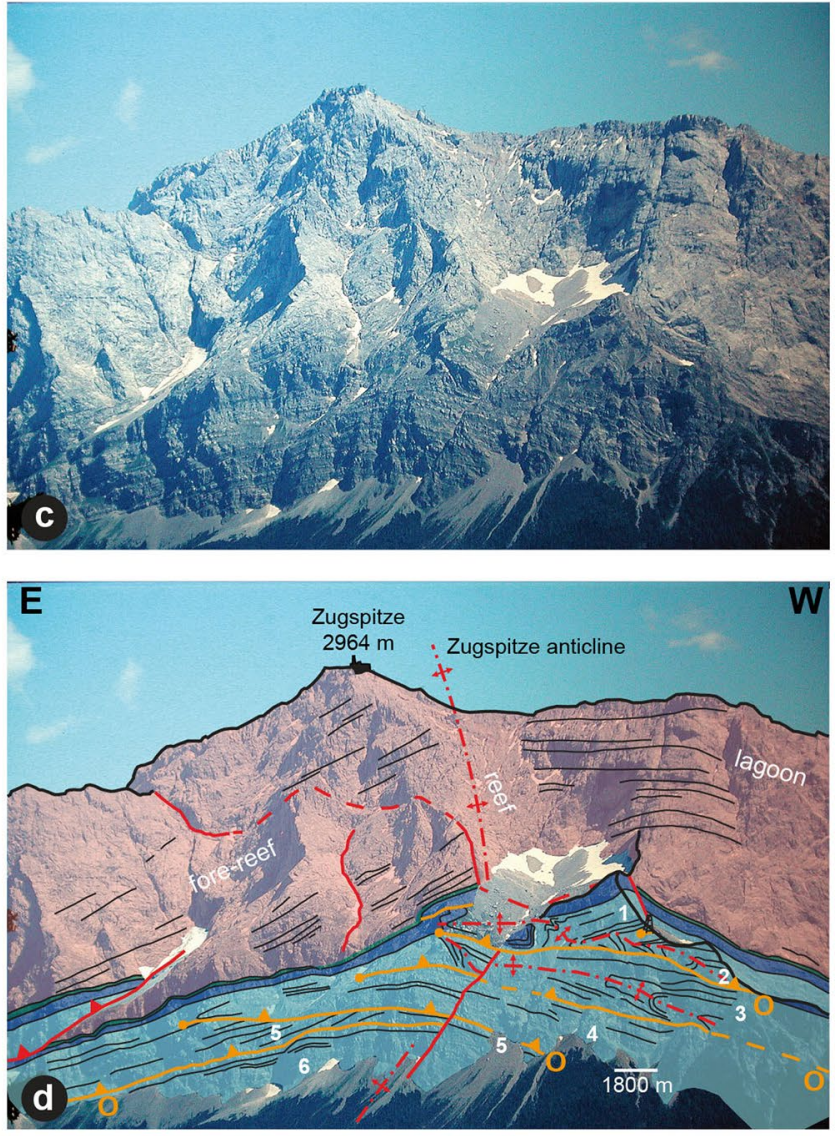

the Zugspitze north face as seen from the North. Slice 1 and 2 cannot be distinguished in this view as the thrust inbetween is parallel to bedding. At least six slices are seen, and the thrust at the base terminates to the East. The Zugspitze anticline („Hauptsattel“ of Miller 1963a) is therefore partly a consequence of stacking of slices within this duplex. However, the anticline also coincides with the transition from lagoon to fore-reef within the Wetterstein carbonate platform. The dip of the clinoforms is therefore also contained in the Zugspitze anticline

tightening of the Reintal syncline and Zugspitze anticline from very open (see also Fig. 11a) at Zugspitze to tight east of Gatterl (see also Fig. 11b). Shortening is increasingly transferred from duplexing to folding toward the East, as the Wetterstein carbonate platform loses thickness and is replaced by the basinal Partnach marls.

The western boundary of this duplex is a branch of the Loisach fault set (Fig. 7). West of the Zugspitze, a branch of the Loisach fault set separates the Lermoos syncline with a km-thick Jurassic succession (Jacobshagen 1965; Köhler 1986) in the W from the easterly adjacent Ehrwald anticline where the Jurassic succession is condensed. Duplexing during activity of the Obermoos thrusts also ends against this Ehrwald branch of the Loisach fault set (Fig. 7). 


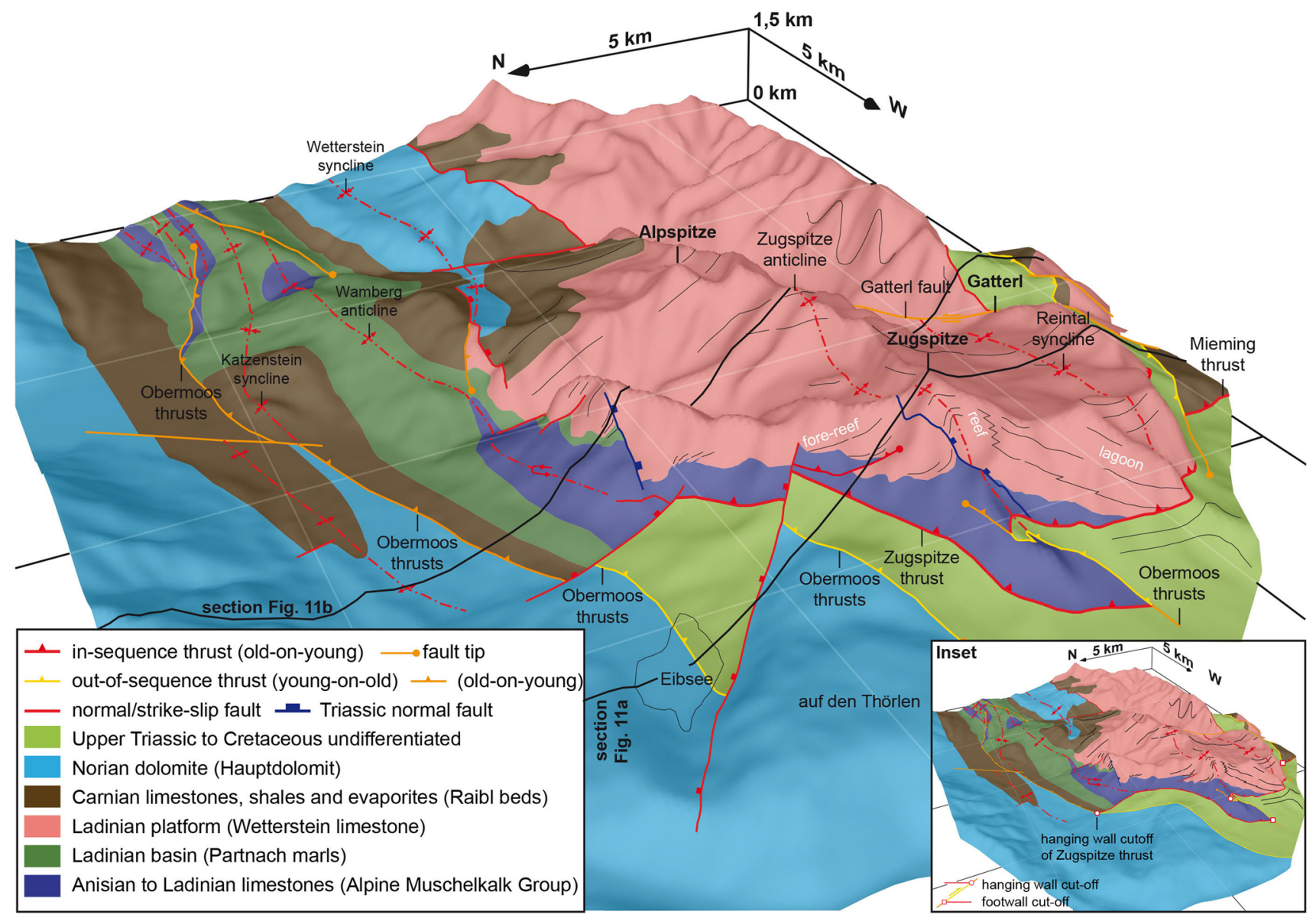

Fig. 13 3D view of the Wetterstein mountains looking to the SE. This oblique view illustrates the Obermoos thrusts loosing offset to the East, where they end within an anticlinorium related to the large scale
Wamberg anticline. Inset shows a further simplified version showing the hanging wall cutoff of the Zugspitze thrust at the Obermoos thrust that is cut out by the normal fault east of Eibsee in the large version

\section{Discussion}

\section{Structural synthesis of the Wetterstein and Mieming mountains}

Here we summarize the structural observations from the Wetterstein and Mieming mountains, and discuss the steps of deformation on a larger scale.

\section{Cretaceous thrusting}

Across the Zugspitze and Mieming thrusts the hanging wall was probably detached in Permian Haselgebirge salt and transported to the NW (Figs. 2, 7b; kinematic data Mieming thrust: diagrams IV and 9 of Fig. 5; kinematic data Zugspitze thrust: Fig. 8). Based on the age of the youngest sediments below both thrusts (see "Sedimentary succession"), Cretaceous thrusting has a maximum age of Hauterivian in the Mieming and Wetterstein mountains. Based on the comparable age, structure and kinematics, we connect the
Mieming and Zugspitze thrusts and thus the Lechtal and Inntal thrust sheets.

\section{Ehrwaldites and E-trending sinistral Puitental faults}

Offset of the Zugspitze and Mieming thrusts by sinistral E-W strike-slip faults is dated by the intrusion of the Albian Ehrwaldite dykes into one of the shear zones (Fig. 10). This is in accordance with the observation of Ehrwaldites in the Reichenhall Formation at the base of the overlying thrust sheet in the Karwendel mountains (Mutschlechner 1954; Trommsdorff 1962; Jerz and Ulrich 1966). Unlike previous studies that argued that the absence of the Ehrwaldite dykes and sills in the hanging wall of the thrusts means that thrusting had not yet taken place (e.g., Trommsdorff et al. 1990; Eisbacher and Brandner 1996), we conclude that the Ehrwaldites postdate major thrust motion. Otherwise the dykes and sills in the hanging wall would have been transported out of the area of observation. 
In their study on the Ehrwaldites, Trommsdorff et al. (1990) argue that these were sourced from a subcontinental mantle, and exclude a subduction setting, i.e., the Penninic subduction underlying the NCA thrust sheets. The setting of the Ehrwaldites is compatible with a foreland setting of NCA nappe stacking in the foreland of Cretaceous intracontinental subduction (von Eynatten and Gaupp 1999; Ortner et al. 2006b, 2016). In such a setting, prior to onset of Penninic subduction, the NCA thrust belt was underlain by continental crust (Janák et al. 2004; Stüwe and Schuster 2010). The Allgäu thrust sheet and CRS had not yet formed and were part of a foreland basin beyond the tip of the Cretaceous orogenic wedge (Fig. 4b) (Gaupp 1982, 1983; Sieberer and Ortner 2018). In such a context, sinistral shearing at E-trending faults can probably be related to intracontinental transform faults in the context of eastward movement of the Iberian microplate relative to Europe (Handy et al. 2010). In paleogeographic reconstructions, such faults have been interpreted to crosscut the Austroalpine domain (e.g., Bechstädt 1978; Weissert and Bernoulli 1985; Channell et al. 1990; Froitzheim et al. 1996; Kövér et al. 2018; Le Breton et al. 2021), and Froitzheim et al. (1996) and Kövér et al. (2018) suggested a Cretaceous sinistral forerunner of the Cenozoic, dextral Periadriatic fault.

Field observations from different parts of the Austroalpine basement units have already documented such E- to NE-trending sinistral faults locally. These faults were active during or intermittent with Cretaceous nappe transport. These are (1) the Albula steep zone that affects the units of the Austroalpine-Penninic contact in Graubünden (Froitzheim et al. 1994), (2) the Gleinalm shear zone of eastern Austria that is connected to formation of the Gleinalm dome and subsidence of the Kainach Gosau basin (Neubauer et al. 1995).

\section{Late Cretaceous out-of-sequence thrusting, folding, and the Höll shear zone}

Ortner (2003a) recognized the out-of-sequence nature of the Cenomanian thrust flooring the western Inntal thrust sheet, which is younger than the more external thrust at the base of the Lechtal nappe (Fig. 4c). However, the eastern Inntal thrust sheet rests on Hauterivian deposits (Figs. 4c, 5). The WNW-striking, dextral Höll shear zone separates these two parts. The compression direction deduced from these faults ( $\sigma_{1}$ in diagram $\mathrm{V}$ of Fig. 5) is roughly perpendicular to fold axes of the western Inntal thrust sheet (e.g., Höllkopf syncline, diagram 8 of Fig. 5), supporting a kinematic connection between Cenomanian NW-transport of the western Inntal thrust sheet and dextral offset across the Höll shear zone. North of the Höll shear zone, folds have consistently ESE- to E-trending axes, pointing to a younger age of these folds. However, both the Höll shear zone and these folds are crosscut by both the Loisach and the Ammer fault sets (Figs. 7, 9). Considering relative ages, the Höll shear zone and the ESE- to E-trending folds are contemporaneous. If the kinematic connection between NW-transport of the western Inntal thrust sheet and the Höll shear zone is accepted, the ESE- to E-trending folds of the Wetterstein and Mieming mountains grew during the Upper Cretaceous, and the divergence of fold axis orientations can be explained by strain partitioning across the Höll shear zone as already suggested by Ortner and Bitterlich (2016) and Kilian et al. (2021). Growth of the NCA orogenic wedge by thrusting and folding only SW of the Höll shear zone would be difficult, as Cenomanian to Campanian (Weidich 1984) growth strata in synorogenic sediments $\mathrm{N}$ of the Wetterstein mountains (10 of Fig. 2) indicate fold growth throughout the Upper Cretaceous at the northern margin of the NCA (Fig. 4b; Ortner and Gaupp 2007; Sieberer 2020). Interpretation of the age of folding from fold axis orientations alone is therefore not possible in the western NCA.

\section{Late Cretaceous to Paleogene out-of-sequence thrusting and the Loisach fault set}

The vertical N-down km-scale offset across the sinistral Puitental fault set localized backthrusting across the Puitental backthrust by the connection of the Kössen marl décollement north and south of the sinistral faults with the decollement in the Raibl evaporites and shales (Fig. 11b). At least $2 \mathrm{~km}$ offset are seen in Fig. 11b, however this number may be underestimated as the Puitental backthrust is kinematically linked with the sinistral, NE-trending Gatterl fault of the Loisach fault set (see "The zone of Upper Triassic to Lower Cretaceous rocks $\mathrm{S}$ of the Wetterstein mountains (Puitental Zone)"), and the southern block moves out of the section.

The out-of-sequence Obermoos thrusts and the Puitental backthrust emplace young on old rocks and have up to $9 \mathrm{~km}$ offset that dies out toward the East. The footwall cutoff at the Obermoos thrusts must be below the rocks in the foreland of the Wetterstein mountains and should be at the base of the sedimentary succession of the Lechtal thrust sheet north of Zugspitze (Fig. 11). Therefore, the Wetterstein mountains must have been in continuation with the Lechtal thrust sheet, as previously claimed (see "The controversy"). However, connecting all footwall and hanging wall cutoffs across the Puitental backthrust implies also continuity of the Zugspitze and Mieming thrusts.

The N- to NNE-direction of transport across the outof-sequence thrusts (diagrams I-III of Fig. 5) suggests a younger, Paleogene age as compared to initial Cretaceous NW-directed stacking. Accordingly, Eisbacher and Brandner (1996) related the Loisach fault set to Paleogene shortening and interpreted these faults as tear faults. Paleogene is roughly the age of collision in the Alps (see "Structural 
evolution of the NCA"), and it seems probable that out-ofsequence thrusting and the associated Loisach fault system is related to collision.

However, in the light of the discussion of "Late Cretaceous out-of-sequence thrusting, folding, and the Höll shear zone", out-of-sequence thrusting, folding and activity of these tear faults might have started already during the Cretaceous. Such an interpretation is supported by the occurrence of the Loisach fault set only $\mathrm{N}$ of the Höll shear zone (Fig. 2). The Loisach fault set in northern part of the NCA extends into the Subalpine Molasse and must have a Miocene age (Figs. 2, 4c) (Schmidt-Thomé 1954; Ortner et al. 2015).

\section{Neogene faulting}

The NW-striking Telfs fault and parallel faults of the Ammer fault set are the youngest faults in the area, truncating all other faults. The Telfs faults is a NW continuation of the Brenner normal fault (BNF of Fig. 2), and has $5 \mathrm{~km}$ dextral offset in the area of Telfs (Fig. 7). Toward the NW close to the core of the Mieming anticline, the fault changes to a thrust and then ends (Miller 1963b; Becke 1983). Most of the offset seems to be consumed by tightening of the anticline. On the regional scale, the Ötztal nappe overthrusted the southernmost NCA in NW direction, delimited by the Telfs fault to the NE, while E-W stretching took place east of the Brenner fault (Ratschbacher et al. 1991). Activity of the Brenner normal fault is well-dated (e.g., Fügenschuh et al. 1997), and most probably, the Telfs fault and the Ammer fault set were active at the same time in the Middle Miocene.

\section{Salt tectonics in the western NCA?}

The geometry of the Mieming and Zugspitze thrusts remains enigmatic. While the geometry of the Mieming thrust in Fig. 5, cutting upsection, could be interpreted in terms of a hanging wall ramp in a fault-bend fold, the Zugspitze thrust cutting downsection in transport direction is much harder to explain. The geometry suggests that the thrust formed out-of-sequence and postdated folding of the hanging wall. However, the low angle of the cutoffs in the hanging wall is mechanically difficult to create. Known examples of out-ofsequence thrusts show that thrusts maintain their dip angle with respect to gravity if they are folded during activity, and create imbricate stacks in the forelimb of anticlines (Gilluly 1960; Boyer 1992). This is supported by evidence from numerical experiments (Fig. 14): in an already folded succession new faults form crosscutting a competent layer. Newly formed faults do not follow the anisotropy between layers 1 and 2 having a large rheological contrast at relatively low angle. Therefore, an origin of the Mieming-Zugspitze thrust as an out-of-sequence thrust is improbable.

An alternative, more speculative explanation would be that the Triassic succession that sits now on top of the Mieming-Zugspitze thrust, originally onlapped a salt anticline, i.e., an anticline formed by rising salt (e.g., Hudec and Jackson 2007). During Cretaceous inversion, the Triassic succession would have been detached along the unconformity, separated from the underlying salt and thrust onto the Schrambach shales. Salt has not been observed in Wetterstein and Mieming mountains, but further east in the Karwendel mountains (KM of Fig. 2) at the base of the Inntal thrust sheet (Schmidegg 1951; Heißel 1978; Spötl 1989). Around the salt occurrence and in its wider vicinity, the Wetterstein limestone is frequently in direct contact with cellular dolomites (Ampferer 1928; Ampferer and Heißel 1950; Krauter 1968; Moser 2008a, b) that are also often found in direct contact with Haselgebirge salt and shales (Spötl 1988) and may represent zones related to salt evacuation toward the surface and related salt tectonics. Such zones are also found in the Mieming mountains close to the core of the Mieming anticline (3 of Fig. 7a; see Becke 1983; Moser 2010) and may suggest the presence of salt in the study area.

The jump of the decollement from the Haselgebirge-Reichenhall succession during Cretaceous initial separation of the allochthon from its basement to the Kössen marls during Paleogene out-of-sequence thrusting may support this interpretation: The original decollement must have gained strength to force it into another position. If the Zugspitze and Mieming thrusts were originally related to salt, evacuation of this salt and welding could have caused strengthening of this contact, and subsequently the activation of the Kössen marl décollement during younger, Cretaceous to Paleogene shortening (compare Kilian and Ortner 2019). Backthrusting across this décollement also created the Holzerwies anticline (3 of Fig. 5) that was one of the main arguments for Miller (1963a) to propose S-directed transport of the Wetterstein mountains. However, this is superimposed after the switch of décollements into the Kössen marls.

\section{General relevance of out-of-sequence thrusting at the Obermoos thrusts}

Out-of-sequence thrusting often leads to inadmissible structures in cross sections, such as truncated anticlines and synclines (e.g., Butler 1987; Morley 1988; McClay 1992). In recent years evidence accumulates on the widespread existence of out-of-sequence thrusting (e.g., Kley 1996-Bolivian Andes; McDowell 1997-Rocky mountains of Montana; Molinaro et al. 2005-Zagros mountains; Olivetti et al. 2010-Peloritani mountains of Sicily; Sieniawska et al. 2010-Polish Carpathians; Ortner et al. 2015-Subalpine Molasse, Alps). In Fig. 15 we illustrate 


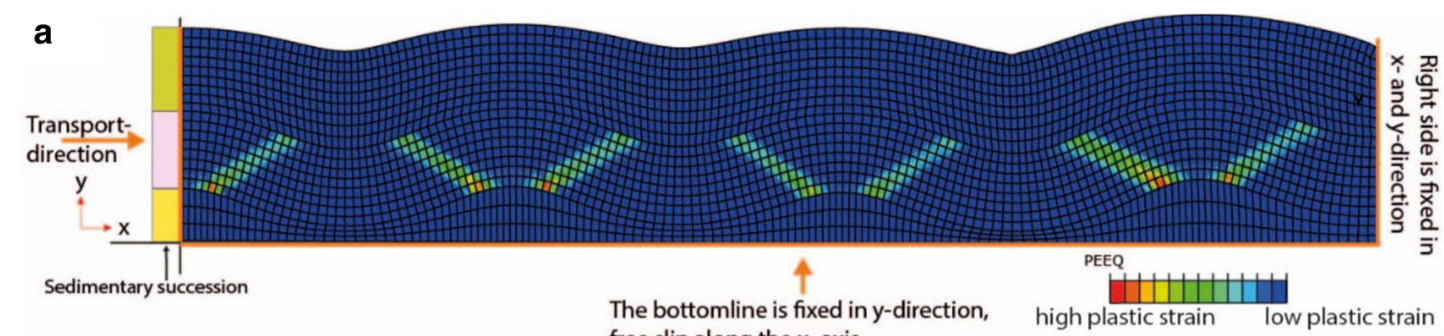

free slip along the $x$-axis.

\begin{tabular}{|l|l|l|l|}
\hline $\mathbf{b}$ & Layer 1 (Bottom) & Layer 2 (Middle) & Layer 3 (Top) \\
\hline Thickness $(\mathrm{m})$ & 600 & 1500 & 1600 \\
\hline Stratigraphy & $\begin{array}{l}\text { Haselgebirge and } \\
\text { Reichenhall Fm. }\end{array}$ & $\begin{array}{l}\text { Alpine Muschelkalk } \\
\text { Group to Hauptdolomit }\end{array}$ & Gosau Group \\
\hline E-Module $\left(\mathrm{kN} / \mathrm{m}^{2}\right)$ & 2000000 & 80000000 & 10000000 \\
\hline Poisson ratio & 0.25 & 0.2 & 0.25 \\
\hline Friction angle $(\varphi)$ & 42 & 41 & 42 \\
\hline Cohesion $(\mathrm{c})$ & 1 & 1 & 1 \\
\hline
\end{tabular}

Fig. 14 Finite-element numerical experiment performed in ABAQUS using the Mohr Coulomb model (linear elastic, ideal plastic model with the failure surface according to Mohr Coulomb). Fault orientation during fault nucleation in a folded sequence is always controlled by the friction angle of the material. Therefore, the small cutoff angles observed are not related to out-of-sequence thrusting. More details of numeric modelling can be found in Kilian et al. (2021). Comparable observations have been published by, e.g., Humair et al. (2020), Najafi et al. (2020) and Heydarzadeh et al. (2020). a Plastic strain in a new increment of shortening in $\mathrm{x}$ direction postdating folding. Three-layer model based on the simplified sedimentary succes- sion of the western NCA. The middle layer with a higher E-Module and a lower friction angle fails where plastic strain is high, and the orientation of these zones is dependent on the coefficient of internal friction. Width of model is $30 \mathrm{~km}$, total thickness of stratigraphic succession $3.7 \mathrm{~km}$. b Input data for the numeric model. The input data base on tests on modelling folding using a linear elastic model and literature: von Soos and Engel (2008) use $\varphi=35-51^{\circ}$ for dense limestone (layer 2); Czech and Huber (1990) give $\varphi=45^{\circ}$ for the Haselgebirge (layer 1) and $\varphi=41^{\circ}$ for Cretaceous marls (equivalent to Gosau Group of layer 3)

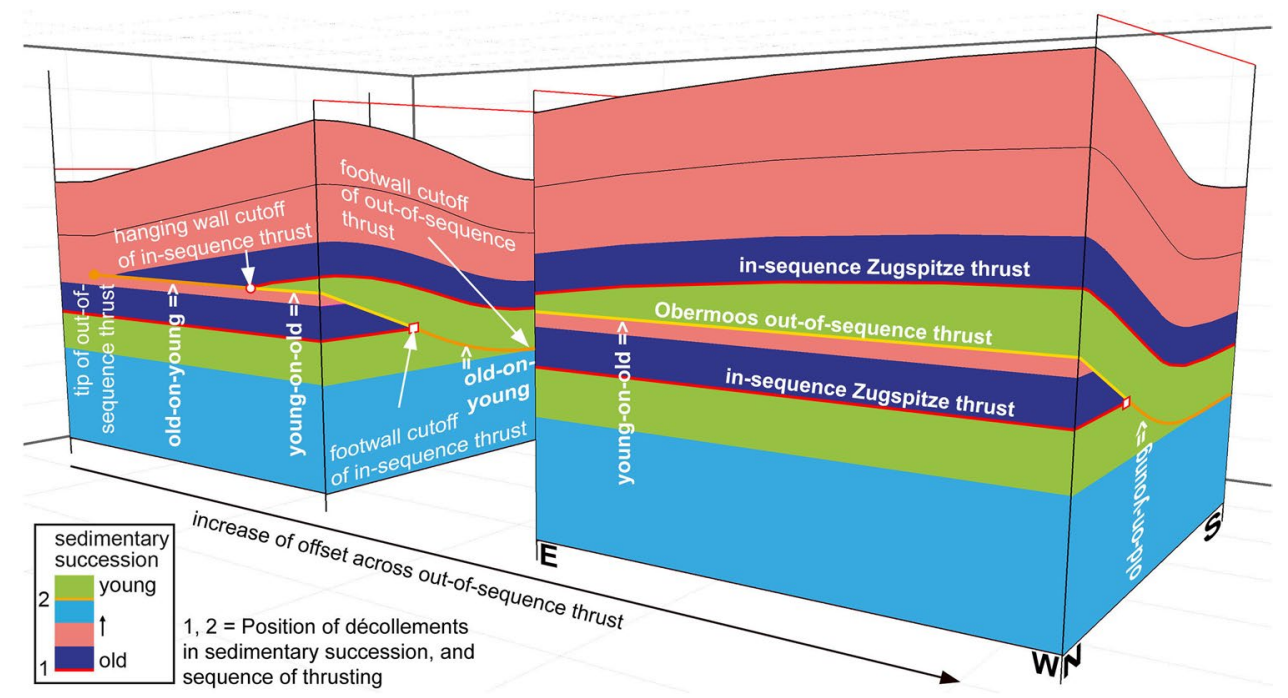

Fig. 15 Geometry of out-of-sequence thrusting in cases when the decollement shifts to a deeper position. Model cut parallel to upper end of ramp. Hanging wall transport on out-of-sequence thrust increases from zero at left to right, where the entire hanging wall has climbed the ramp. Old-on-young contacts and young-on-contacts across out-of-sequence thrust are color coded, and alternate depend- ing on position on the thrust (left). After the entire hanging wall has climbed the ramp, the length of the young-on-old contact on the upper footwall increases. The coloring of stratigraphic units is similar to Fig. 13, but is used here in a more general way to distinguish old and young deposits 
the case of two parallel décollements (position illustrated in legend in lower left). Décollement 1 is used during initial in-sequence emplacement of old on young rocks (Zugspitze thrust on right side of Fig. 15) and is abandoned after an increase of strength related to salt expulsion or release of overpressure. Subsequent shortening uses décollement 2 (Fig. 15) at the base of the youngest unit. The out-ofsequence thrust related to these shortening ramps across the older in-sequence thrust. Across the out-of-sequence thrust, old-on-young relationships are observed in the hinterland of the footwall cutoff of the in-sequence thrust, and in the foreland of the hanging wall cutoff (orange segments in Fig. 15). Young-on-old relationships are observed across the segment between the footwall and hanging wall cutoff (yellow segments in Fig. 15). This latter segment increases in length as the hanging wall travels across the upper footwall flat of the out-of-sequence thrust. The fault tip and the old-on-young and young-on-old segments of the out-of-sequence thrust are also visible in the inset of Fig. 13. The right side of Fig. 15 gives the local names used in this study.

\section{Tectonic subdivision of the NCA}

\section{Revised tectonic subdivision of the western NCA}

Joining the Zugspitze and Mieming thrusts by connecting the hanging- and footwall cutoffs across the out-of-sequence thrusts (Fig. 11) leads to one continuous thrust that disappears into the subsurface north of the Wetterstein mountains.
The next old-on-young contact to the north is the contact of the Lechtal on top of Allgäu thrust sheet close to the northern margin of the NCA according to the old scheme (Figs. 2, 3a). In our interpretation, this contact is the continuation of the Zugspitze and Mieming thrusts (Fig. 16a). This interpretation renders the accepted tectonic subdivision of the western NCA of Ampferer (1912), Heißel (1958) and Tollmann (1976b) obsolete. Here we apply the new subdivision suggested by Kilian and Ortner (2019), provide definitions of the new units and discuss it on the scale of the western NCA (Fig. 17).

Kilian and Ortner (2019) introduced new terms and renamed the units including most of the former Lechtal and Inntal thrust sheets as the Karwendel thrust sheet, and the underlying unit the Tannheim thrust sheet. The latter includes the former Allgäu thrust sheet, the tectonic windows of the Puitental Zone and the eastern Karwendel mountains, and the Lechtal thrust sheet $\mathrm{E}$ of Innsbruck (Fig. 2). All units defined here have been thrust onto an upper footwall flat of a ramp-flat-system, and thus emplace old rocks on young rocks. We do not use out-of-sequence tectonic boundaries that emplace young on old rocks to delimit tectonic units.

Definition of the Karwendel thrust sheet We name the Karwendel thrust following Ampferer (1902), who was the first to describe this thrust in the Karwendel Mountains. The Karwendel thrust sheet is a composite tectonic unit of the western NCA that was emplaced between the Hauterivian

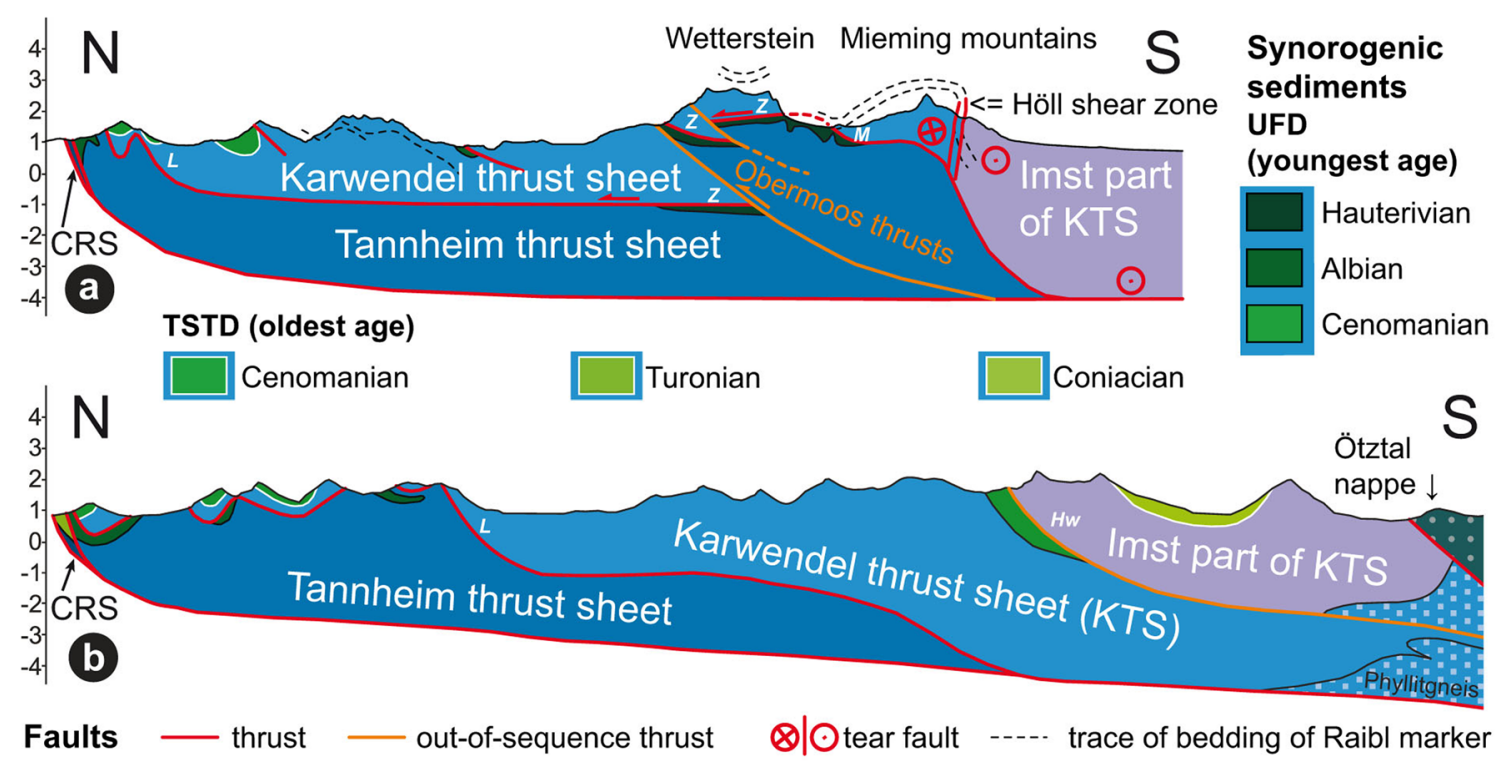

Fig. 16 Conceptual cross sections of the NCA using the tectonic subdivision proposed by Kilian and Ortner (2019). Cretaceous synorogenic sediments color-coded for type (UFD = upper footwall deposits; $\mathrm{TSTD}=$ thrust-sheet-top deposits) and age. a Zugspitze section using the new tectonic subdivision. Thickening of the NCA wedge below the Wetterstein and Mieming mountains is accomplished by the outof-sequence Obermoos thrusts. b Reinterpreted section west of the study area using the revised tectonic subdivision 


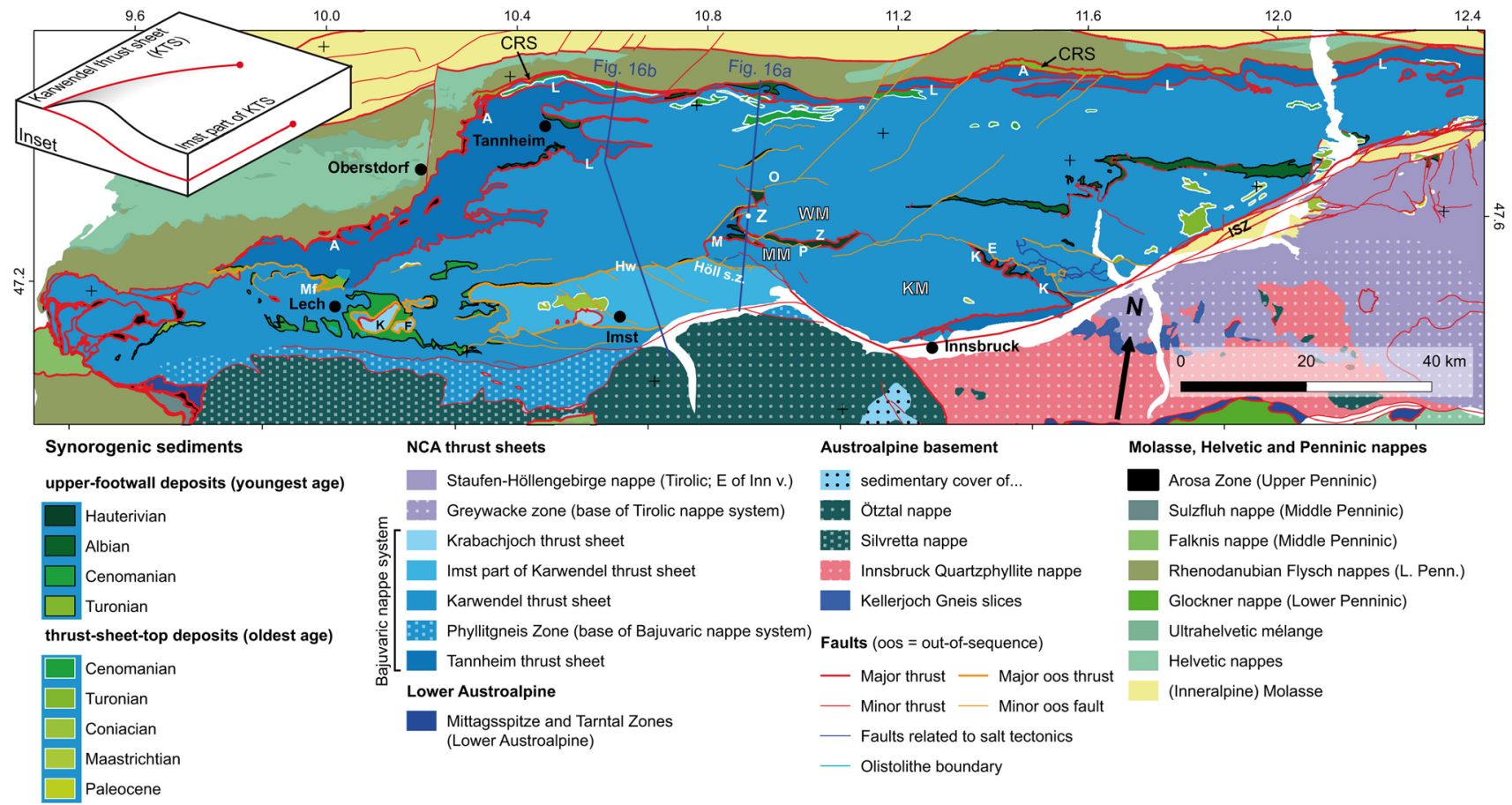

Fig. 17 New tectonic subdivision of the western NCA. This subdivision is in accordance with the distribution of all synorogenic sediments of the western NCA. All thrusts and related tear faults that are not in the general foreland-propagating thrust sequence are classified as out-of-sequence thrusts/faults. Local names of thrusts from $\mathrm{W}$ to $\mathrm{E}: \mathrm{Mf}=$ Mohnenfluh thrust, $\mathrm{A}=$ Allgäu thrust, $\mathrm{L}=$ Lechtal thrust,
$\mathrm{Hw}=$ Heiterwand thrust, $\mathrm{M}=$ Mieming thrust, $\mathrm{O}=$ Obermoos thrust, $\mathrm{P}=$ Puitental backthrust, $\mathrm{Z}=$ Zugspitze thrust, $\mathrm{K}=$ Karwendel thrust, $\mathrm{E}=$ Eng thrust; $\mathrm{CRS}=$ Cenoman-Randschuppe, $\mathrm{K}=$ Krabachjoch Klippe, F=Fallesin Klippe; ISZ=Inntal shear zone; s.z. = shear zone. Inset in upper left shows an extremely simplified sketch of the relation between the Karwendel thrust sheet and its Imst part and Coniacian. In the Karwendel Mountains it is floored by the Karwendel thrust, in the Mieming Mountains by the Mieming thrust, in the Wetterstein Mountains by the Zugspitze thrust, which all have a Hauterivian age (Figs. 4c, 17). In the more external NCA, the Karwendel thrust sheet rests on the Albian Lechtal thrust named by Ampferer and Hammer (1911) E of Lech, whereas W of Lech, it lies on the Coniacian Mohnenfluh thrust. The latter thrust developed out-of-sequence, postdating the more external Allgäu thrust of Turonian age. The Lechtal and Mohnenfluh thrusts merged in the Turonian or later. Therefore, the Karwendel thrust sheet was assembled and separated from the underlying units during progressive Early to Late Cretaceous thrust transport.

The Karwendel thrust sheet overlies the Tannheim thrust sheet over most of its extent. Only in the westernmost NCA, where the Tannheim thrust sheet ends, the Karwendel thrust sheet overlies the Arosa zone across a thrust of Turonian age.

The Imst part of the Karwendel thrust sheet is named after the city of Imst (Fig. 17). West of the Höll shear zone, this unit repeats the main Karwendel thrust sheet across the Heiterwand thrust (Hahn 1911) of Cenomanian age. The Höll shear zone, sitting on the Mieming thrust separates the main Karwendel thrust sheet from its Imst part, and allows
NW-directed movement of the Imst part relative to the main Karwendel thust sheet. The Heiterwand thrust at the base of the Imst part of the Karwendel thrust sheet appears and gains offset where the Lechtal thrust starts to lose offset, and ends NE of Lech (Fig. 17).

The Tannheim thrust sheet tapers to the south below the Imst part of the Karwendel thrust sheet west of the Höll shear zone (Figs. 16b, 18a) (Eisbacher et al. 1990). East of the Höll shear zone, it continues further to the southeast, and reappears at the surface near Innsbruck (Fig. 17). Therefore, a lateral ramp (seen in Fig. 18b) in the basal décollement is necessary that separates the Tannheim thrust sheet from the Karwendel thrust sheet and localizes the Höll shear zone at surface (Fig. 16b).

In the Arlberg region SE of Lech, and W of Imst, the Imst part of the Karwendel thrust sheet is overlain by klippen belonging to the Krabachjoch thrust sheet (Ampferer 1914b). The Krabachjoch thrust branches from the Heiterwand thrust. However, its age remains unknown, as there are no synorogenic sediments in its footwall. We include the Fallesin klippe (F of Fig. 17) into the Krabachjoch thrust sheet because of its position SE of the branch line, and because of its anchimetamorphism comparable to the main Krabachjoch Klippe (K of Fig. 17) (Petschick 1989). 
Fig. 18 Block diagrams illustrating the lateral relationship between the Zugspitze and Lechtal cross sections of Fig. 16. a Geometry of the nappe stack at the end of the Cenomanian. The Karwendel thrust sheet had already been stacked between the Hauterivian and Albian, and the Imst part of the Karwendel thrust sheet had been emplaced during the Cenomanian. East of the Höll shear zone, the Tannheim thrust sheet reaches further to the south, and a lateral ramp or tear fault is required that localizes the Höll shear zone at surface (see also Fig. 16a). b During the Latest Cretaceous to Paleogene, the Obermoos out-of-sequence thrusts stack the already existing nappe pile. In this view, the Imst part of the Karwendel thrust sheet south of the Höll shear zone moved toward the observer. Transport during out-of-sequence thrusting was almost perpendicular to transport during preceding stacking
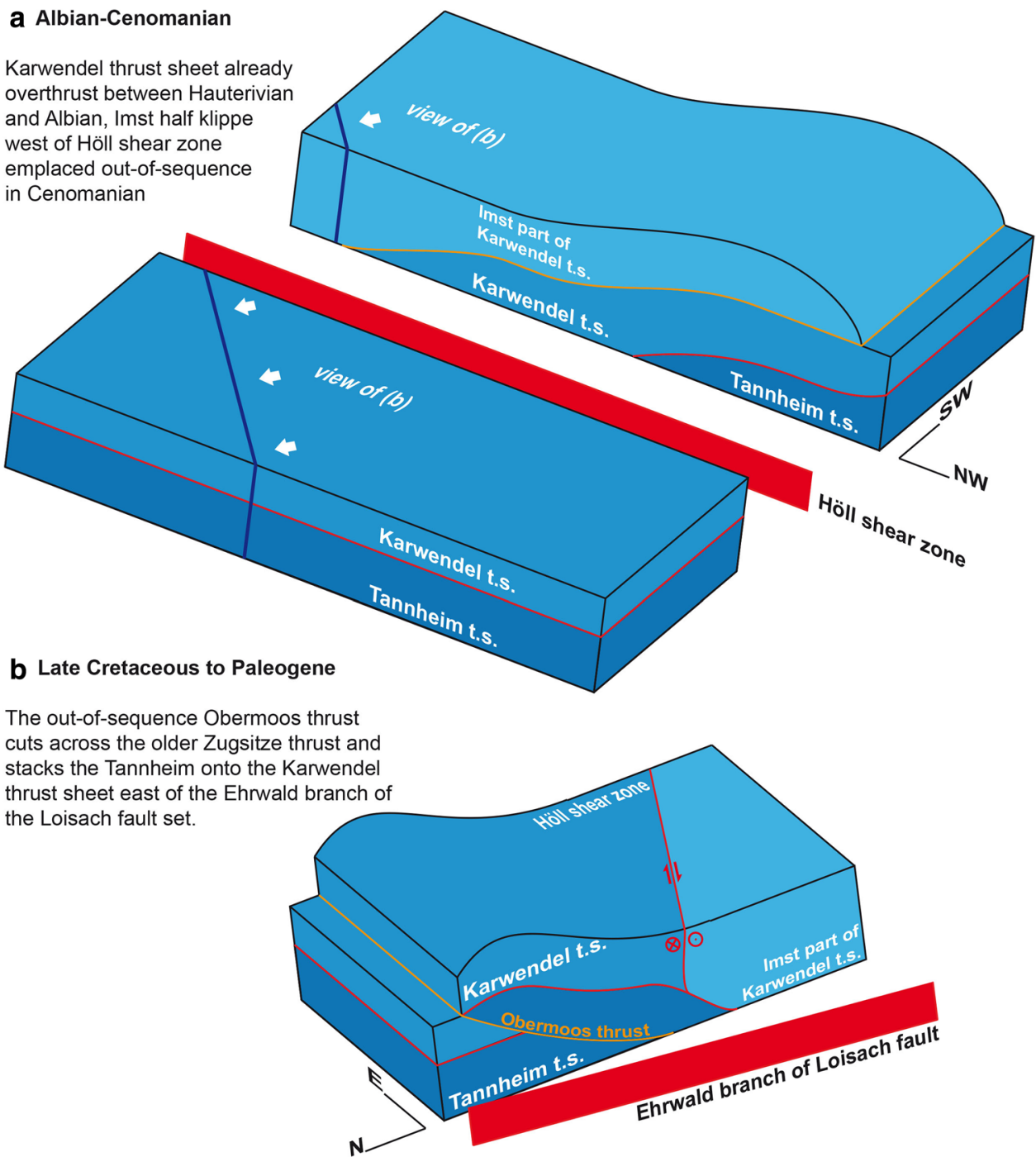

Definition of the Tannheim thrust sheet The name of the Tannheim thrust sheet derives from the Tannheim village located within the thrust sheet (Fig. 17). The Tannheim thrust sheet was transported on the Turonian Allgäu thrust onto the CRS (Fig. 4b, c) and the Arosa Zone west of $10.4^{\circ} \mathrm{E}$ (Fig. 17). It forms a narrow strip at the northern margin of the NCA, except in the Allgäu region around Tannheim and SE of Oberstdorf. Locally, the Allgäu thrust and the underlying CRS/Arosa Zone are cut out at the northern margin of the NCA. There, the Tannheim thrust sheet rests directly on the Rhenodanubian Flysch nappes across a Paleogene thrust. The Tannheim thrust sheet is also exposed in some windows in the more internal part of the NCA, like the Puitental window between the Mieming and Zugspitze thrusts, and the Eng Window between the Karwendel and Eng thrusts (Fig. 17), where the Tannheim thust sheet was exhumed by duplexing in response to Late Cretaceous erosion (Kilian et al. 2021).
Why do we need new names? The names of nappes or thrust sheets are closely connected to the definition of the respective units. Previous authors (Ampferer 1912; Heißel 1958; Tollmann 1970a, b, 1976b) emphasized the existence of thrusts or faults on all sides of their nappes, and none of them included the ages of the thrusts nor thrust geometry in the definitions of the Allgäu-, Lechtal, and Inntal nappes (see "Kinematics of thrusts"). Even if many of the boundaries of the thrust sheets defined here coincide with previously defined nappe boundaries that have been correctly recognized, we exclude out-of-sequence thrusts that stack young on old rocks and that do not have the geometry of an allochthon on an upper footwall flat.

Our definition includes thrust ages and thrust geometry. Therefore, the Tannheim and Karwendel thrust sheets were stacked at a defined time and have a defined geometry (see "Definition of the Karwendel thrust sheet", "Definition of the Tannheim thrust sheet"). Any solution that just combines 
the names of the former units, such as Inntal-Lechtal thrust sheet, as suggested by Mandl et al. (2017) in a poster, would need specification which part of the former Lechtal thrust sheet is meant. Such a solution also perpetuates inconsistencies in timing of thrust transport.

What do the old names mean in the new subdivision? The Allgäu thrust sheet is equivalent to the new Tannheim thrust sheet minus the units exposed in the Puitental and eastern Karwendel tectonic windows (Fig. 17). The Allgäu- and Lechtal thrust sheets of Ampferer (1912) are separated by the Lechtal thrust at the base of the external Karwendel thrust sheet. The Inntal thrust sheet is floored by the Karwendel thrust and the Heiterwand thrust. The main bodies of the Lechtal and Inntal thrust sheets are separated by the out-of-sequence Heiterwand thrust west of the Höll shear zone, and the out-of-sequence Puitental backthrust and Eng thrust east of the Höll shear zone (Figs. 7, 17).

Relationship of the Karwendel and Tannheim thrust sheets to the Tirolic and Bajuvaric nappe systems Connecting the main bodies if the former Lechtal and Inntal thrust sheets also connects the Tirolic and Bajuvaric thrust systems in the western NCA as defined by Hahn (1913a). Two lines of argument have been used to solve this problem:

1. Kilian and Ortner (2019) concluded that the new Karwendel thrust sheet should be part of the Tirolic thrust system, based on (i) the observation of a Lower Cretaceous Roßfeld-type sedimentary succession on the eastern Karwendel thrust sheet (compare Hahn 1912, p. 341), and (ii) the presence of Upper Jurassic allodapic limestones in the same area. This is in accordance with the conclusions of Mandl et al. (2017).

2. The thrust sheets of the Tirolic nappe system have a sedimentary contact to the Greywacke Zone of the Noric nappe system (Fig. 1; Tirolic-Noric nappe system) (Hahn 1912, p. 340; Schmid et al. 2004; Schuster 2015), while the Bajuvaric nappe system is attached to the Silvretta basement nappe (Fig. 1) (Frank 1987; Janák et al. 2004). The Karwendel thrust sheet has a sedimentary contact to the Phyllitgneis Zone of the Silvretta nappe in its westernmost portion (Stingl 1984; Spiess 1985; Rockenschaub 1990; Nowotny et al. 1992; Ortner et al. 2006a), also including its Imst part (Fig. 16b) (Eisbacher et al. 1990). Consequently, the Karwendel thrust sheet must be part of the Bajuvaric nappe system.

If the Karwendel thrust sheet would be part of the Tirolic nappe system (case 1), the latter would have a sedimentary contact to both the Phyllitgneis Zone and the Greywacke Zone. However, the Pyllitgneis Zone is a part of the Silvretta nappe (Rockenschaub 1990; Nowotny et al. 1992), the lowermost unit of the Upper Austroalpine nappe edifice, while the Greywacke Zone is a tectonically much higher unit (Schmid et al. 2004; Schuster 2015), with the Innsbruck Quartzphyllite nappe and the Ötztal basement nappe and equivalents in between (see cross sections in Ortner et al. 2006b). It seems improbable that such a major boundary has almost zero offset within the NCA NE of Lech (Fig. 17). Alternatively, the Karwendel thrust sheet and thus all thrust sheets of the western NCA are part of the Bajuvaric nappe system (case 2). In such a case, the boundary between the Bajuvaric and Tirolic unit is the Paleogene Brixlegg thrust that is largely cut out by the Oligo-Miocene sinistral Inntal shear zone (ISZ of Fig. 17), and that was identified in the TRANSALP seismic line (Ortner et al. 2006b). Unfortunately, the Brixlegg thrust is another out-of-sequence thrust postdating Cretaceous nappe stacking. The similarity of the easternmost Karwendel thrust sheet and the Staufen-Höllengebirge nappe in terms of facies (see case 1 above) suggests that these were initially laterally adjacent until the Cretaceous. However, the boundary of the Karwendel thrust sheet and the Staufen-Höllengebirge nappe is not within the scope of this contribution, and will be discussed elsewhere. We conclude that the Karwendel thrust sheet is part of the Bajuvaric nappe system based on its primary sedimentary contact to the Silvretta basement nappe.

\section{Thrust distance and rates}

Combining the former Lechtal and Inntal thrust sheets increases the thrust distance to at least $38 \mathrm{~km}$ in the Karwendel mountains (Kilian and Ortner 2019), and to $35 \mathrm{~km}$ in the Wetterstein and Mieming mountains, which is the surface $\mathrm{N}-\mathrm{S}$ length of the Karwendel thrust sheet (Fig. 16a). This value excludes folding and minor thrusting within the unit. Considering NW-directed transport (see "Structural evolution of the NCA", "Western and southern flank of the Wetterstein and Mieming mountains"; Fig. 2) increases these values to $41 \mathrm{~km}$ for both cross sections. We consider a thrust sheet travelling across an upper footwall flat that covers the upper-footwall-flat deposition zone and ends deposition (Fig. 6). Thrust advance rates can be deduced when the age of the youngest sediments below a thrust sheet at two points arranged in thrust direction is known: The Karwendel thrust sheet is floored by upperfootwall deposits that are exposed close to the northern margin of the NCA (label 8 of Fig. 2), where these reach into the Albian (Gaupp 1982). S of Zugspitze, upper-footwall deposits are found within the Puitental Zone and at Eibsee (labels 4 and 5 of Fig. 2), where they reach into the Hauterivian (Vidal 1953; Miller 1963c); the rate of thrust propagation using the $27 \mathrm{~km}$ distance between the two locations amounts to $0.06 \mathrm{~cm} /$ year in NW-SE direction, which is rather slow as compared to active present-day 
orogenic wedges (e.g., $1.2 \mathrm{~cm} /$ year, Himalayan thrust front-Wesnousky et al. 1999; $0.45 \mathrm{~cm} /$ year, thrust front of the central Andes-Schmidt et al. 2011; $3 \mathrm{~cm} /$ year, Taiwan orogenic front-Malavieille et al. 2021).

\section{Conclusions}

Based on our structural analysis, we propose a new tectonic subdivision of the western NCA. This subdivision has only two large thrust sheets, the tectonically deeper unit being the Tannheim thrust sheet, the tectonically higher the Karwendel thrust sheet. The observation of out-of-sequence thrusts that crosscut and locally repeat the in-sequence thrust and end laterally, allows to keep the Wetterstein mountains in stratigraphic contact with their northeastern foreland and, at the same time, sitting on the thrust at the base of the Karwendel thrust sheet. This solves a 100 -year-old controversy (see Sect. 1.3).

The following steps are evident in the kinematic evolution of the Wetterstein and Mieming mountains (Fig. 19):

1. Between the Hauterivian and Albian, the Karwendel thrust sheet travelled at least $40 \mathrm{~km}$ to the $\mathrm{NW}$ over the Tannheim thrust sheet, possibly detached on salt.

2. Albian activity of E-trending sinistral faults (Puitental faults) separates Cretaceous NW-directed emplacement of thrust sheets from younger N- to NNE-directed outof-sequence thrusting. These faults crosscut the entire nappe stack and reached into the underlying crust and mantle, facilitating the ascent of mantle-derived melts leading to intrusion of basanitic dykes (Ehrwaldites) into the shear zones in the late Albian. These faults have kmscale vertical, $\mathrm{N}$-down offset.

3. Renewed Cenomanian NW-directed transport emplaced the Imst part of the Karwendel thrust sheet $S$ of the WNW-striking Höll shear zone. Strain partitioning across the Höll shear zone caused N- to NNE-directed contraction north of this fault.

4. The steps across the Puitental faults localized out-ofsequence thrusting, both foreland-directed (Obermoos thrusts), and hinterland-directed (Puitental backthrust) that dissected Cretaceous thrust sheet boundaries. These thrusts have km-scale offsets and are kinematically linked to sinistral, NE-striking tear faults of the Loisach fault set. Both formed probably during collision and have a Paleogene age in the Wetterstein and Mieming mountains, but a Miocene age in the northern, most external part of the NCA.

5. The Telfs fault is directly linked to Miocene NWdirected thrusting of the Ötztal basement nappe onto the NCA.

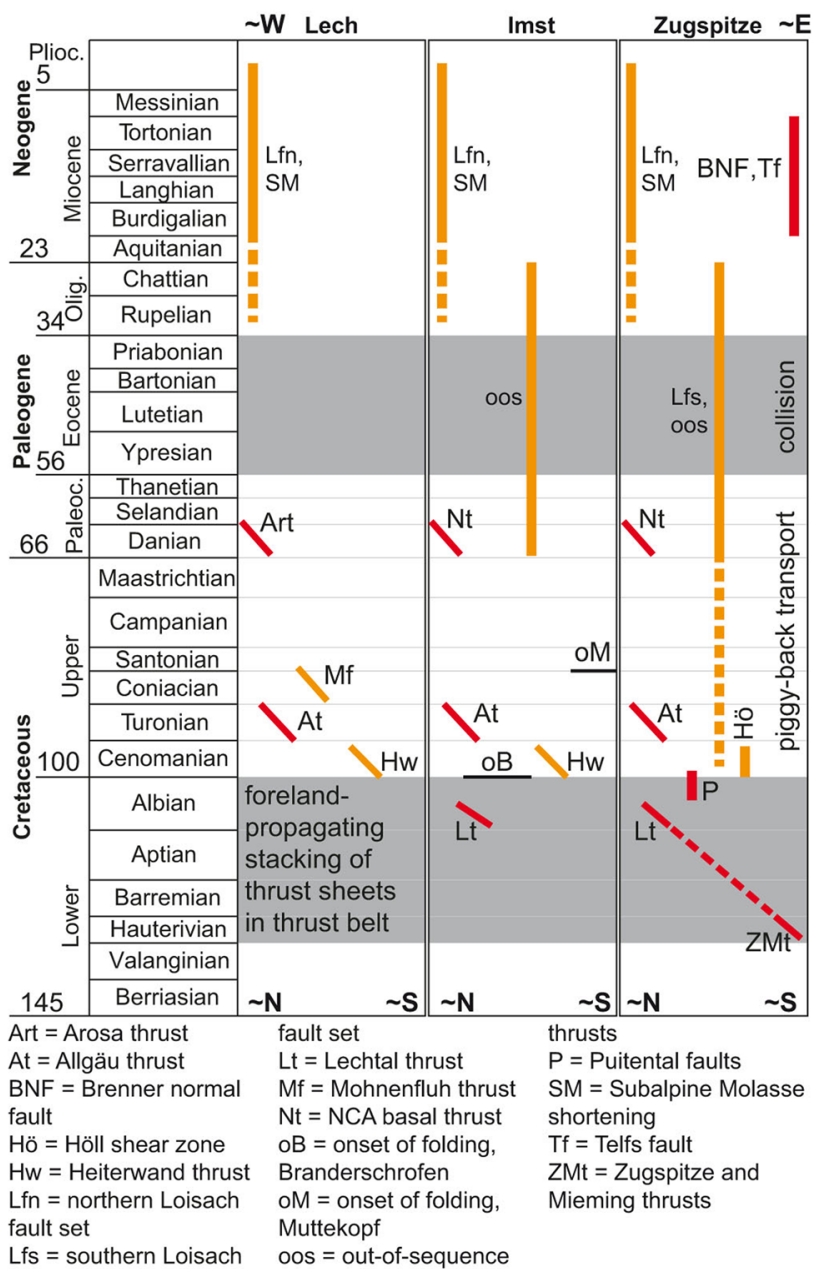

Fig. 19 Timing of structures described in three $\mathrm{N}-\mathrm{S}$ transects, arranged from $\mathrm{W}$ to $\mathrm{E}$. As a consequence of the composite nature of the thrust sheets, only the timing of the thrusts at their base can be depicted. Out-of-sequence thrusts and related structures shown in orange, other thrusts in red. Timescale simplified from Cohen et al. (2013; updated)

Supplementary Information The online version contains supplementary material available at https://doi.org/10.1007/s00531-021-02128-3.

Acknowledgements High resolution DEMs and orthophotographic images were used to analyze stratal and fault geometries. These were provided by the state of Tyrol and the Bavarian Agency for Digitisation, High-Speed Internet and Surveying, which is greatly acknowledged. We thank Petroleum Experts Ltd. who provided their Move software package that was used to create Figs. 3, 4, 11, 13, 15 and 16. The work of Sinah Kilian was supported by the state of Tyrol (Tiroler Wissenschaftsfonds, grant UNI-0404/2295) and the Doctoral programme of the University of Innsbruck (Grant 2018/GEO-8). We thank Gabor Heja (Budapest) for help during field work. We acknowledge the comments of S. Schmid and two anonymous reviewers, and of the thematic editor N. Froitzheim. Especially the rigorous review of S. Schmid helped to sharpen the ideas presented in this paper.

Funding Open access funding provided by University of Innsbruck and Medical University of Innsbruck. 
Open Access This article is licensed under a Creative Commons Attribution 4.0 International License, which permits use, sharing, adaptation, distribution and reproduction in any medium or format, as long as you give appropriate credit to the original author(s) and the source, provide a link to the Creative Commons licence, and indicate if changes were made. The images or other third party material in this article are included in the article's Creative Commons licence, unless indicated otherwise in a credit line to the material. If material is not included in the article's Creative Commons licence and your intended use is not permitted by statutory regulation or exceeds the permitted use, you will need to obtain permission directly from the copyright holder. To view a copy of this licence, visit http://creativecommons.org/licenses/by/4.0/.

\section{References}

Ampferer O (1902) Bericht über die Neuaufnahme des Karwendelgebirges. Verh Geol Bundesanst 1902:274-276

Ampferer O (1912) Gedanken über die Tektonik des Wettersteingebirges. Verhandlungen Der Kk Geologischen Reichsanstalt 1912:197-212

Ampferer O (1914a) Besprechung mit O. Schlagintweit, K. Ch. v. Loesch und H. Mylius über das Wettersteingebirge. Verhandlungen Der Kk Geologischen Reichsanstalt 1914:338-352

Ampferer O (1914b) Über den Bau der westlichen Lechtaler Alpen. Jahrbuch Der k k Geologischen Reichsanstalt 64:307-325

Ampferer O (1928) Die Reliefüberschiebung des Karwendelgebirges. $\mathrm{Jb}$ Geol Bundesanst 78:241-256

Ampferer O (1931) Zur neuen Umgrenzung der Inntaldecke. Jb Geol Bundesanst 81:25-48

Ampferer O (1942) Geologische Formenwelt und Baugeschichte des östlichen Karwendelgebirges. Denkschriften d Akad d Wiss 106(1):1-95

Ampferer O, Hammer W (1911) Geologischer Querschnitt durch die Alpen vom Allgäu zum Gardasee. Jahrbuch Der Kk Geologischen Reichsanstalt 61:531-710

Ampferer O, Heißel W (1950) Das östliche Karwendel: Erläuterungen zur geologischen Karte des östlichen Karwendel und des Achensee-Gebietes. Wagner, Innsbruck

Ampferer O, Ohnesorge T (1924) Erläuterungen zur Geologischen Spezialkarte der im Reichsrate vertretenen Königreiche und Länder der österreichisch-ungarischen Monarchie 1:75.000, 5046 Zirl und Nassereith. k. k. Geologische Reichsanstalt, Wien

Auer M, Eisbacher GH (2003) Deep structure and kinematics of the Northern Calcareous Alps (TRANSALP profile). Int J Earth Sci 92:210-227. https://doi.org/10.1007/s00531-003-0316-0

Bechstädt T (1978) Faziesanalyse permischer und triadischer Sedimente des Drauzuges als Hinweis auf eine großräumige Lateralverschiebung innerhalb des Ostalpins. Jb Geol Bundesanst 121:1-121

Bechstädt T, Mostler H (1974) Mikrofazies und Mikrofauna mitteltriadischer Beckensedimente der nördlichen Kalkalpen Tirols. Geol-Paläontol Mitt Innsbruck 4:1-74

Bechstädt T, Mostler H (1976) Riff-Becken-Entwicklung in der Mitteltrias der westlichen nördlichen Kalkalpen. Zeitschr Dt Geol Ges 127:271-289

Becke M (1983) Zur Geologie des Mieminger Gebirges. GeolPaläontol Mitt Innsbruck 12:317-340

Behrmann JH, Tanner DC (2006) Structural synthesis of the Northern Calcareous Alps, TRANSALP segment. Tectonophysics 414:225-240. https://doi.org/10.1016/j.tecto.2005.10.018

Bergen KJ, Shaw JH (2010) Displacement profiles and displacement-length scaling relationships of thrust faults constrained by seismic-reflection data. GSA Bull 122(7-8):1209-1219. https://doi.org/10.1130/B26373.1

Beurlen (1944) Zum Problem der Inntaldecke. Sitzungsberichte der mathematisch-naturwissenschaftlichen Abteilung der Bayerischen Akademie der Wissenschaften zu München 1943:239-264

Bischof M, Garber C, Mackowitz J, Postl M, Ortner H (2010) Jurassische Beckenbildung in den westlichen nördlichen Kalkalpen. PANGEO 2010 Abstracts. J Alpine Geol 52:93-94

Bögel H (1960) Der geologische Bau des Wettersteingebirges und seiner Umgebung. http://www.dav-bibliothek.de/webOPAC/ 01_Alpenvereins-Publikationen/01_AV-Jahrbuch/AV_Jahrb uch_085.1960-web.pdf. Accessed 16 Nov 2021

Boyer SE, Elliott D (1982) Thrust systems. AAPG Bull 66:1196-1230

Boyer SE (1992) Geometric evidence for synchronous thrusting in the southern Alberta and northwest Montana thrust belts. In: McClay KR (ed) Thrust tectonics. Chapman \& Hall, London, pp 377-390. https://doi.org/10.1007/978-94-011-3066-0_34

Brandner R (1984) Meeresspiegelschwankungen und Tektonik der NW-Tethys. Jb Geol Bundesanst 126(4):435-475

Butler RWH (1987) Thrust sequences. J Geol Soc Lond 144:619-634

Channell JET, Brandner R, Spieler A, Smathers NP (1990) Mesozoic paleogeography of the Northern Calcareous Alps-evidence from paleomagnetism and facies analysis. Geology 18:828831. https://doi.org/10.1130/0091-7613(1990)018\%3c0828: MPOTNC\%3e2.3.CO;2

Cohen KM, Finney SC, Gibbard PL, Fan J-X (2013) The ICS International Chronostratigraphic Chart. Episodes 36:199-204 (updated)

Czech J, Huber H (1990) Gesteinskennwerte aus Laborversuchen. Felsbau 8(3):129-133

Davis K, Burbank DW, Fisher D, Wallace S, Nobes D (2005) Thrustfault growth and segment linkage in the active Ostler fault zone. New Zealand. J Struct Geol 27(8):1528-1546. https:// doi.org/10.1016/j.jsg.2005.04.011

Decker K, Peresson H, Faupl P (1994) Die miozäne Tektonik der östlichen Kalkalpen: Kinematik, Paläospannungen und Deformationsaufteilung während der "lateralen Extrusion" der Zentralalpen. Jb Geol Bundesanst 137:5-18

Doben K (1970) Erläuterungen zur geologischen Karte von Bayern, Blatt Nr. 8241 Ruhpolding. Geologische Karte von Bayern 1:25000. Bayerisches Geologisches Landesamt, München

Doben K (1985) Erläuterungen zum Blatt Nr. 8334 Kochel a. See. Geologische Karte von Bayern 1:25000. Bayerisches Geologisches Landesamt, München

Eisbacher GH, Brandner R (1995) Role of high-angle faults during heteroaxial contraction, Inntal thrust sheet, Northern Calcareous Alps, western Austria. Geol-Paläontol Mitt Innsbruck 20:389-406

Eisbacher GH, Brandner R (1996) Superposed fold thrust structures and high angle faults, northwestern Calcareous Alps, Austria. Eclogae Geol Helv 89:553-571. https://doi.org/10.5169/ seals- 167913

Eisbacher GH, Linzer G-H, Meier L (1990) A depth extrapolated structural transect across the Northern Calcareous Alps of Western Tirol. Eclogae Geol Helv 83(3):711-725. https://doi. org/10.5169/seals-166610

Elliott D (1976) The energy balance and deformation mechanisms of thrust sheets. Phil Trans R Soc Lond Part A 283:289-312

Faupl P, Wagreich M (2000) Late Jurassic to Eocene paleogeography and geodynamic evolution of the Eastern Alps. Mitt Österr Geol Ges 92:79-94

Fernández O, Habermüller M, Grasemann B (2020) Hooked on salt: rethinking Alpine tectonics in Hallstatt (Eastern Alps, Austria). Geology 49(3):325-329. https://doi.org/10.1130/g47981.1

Ferreiro Mählmann R, Morlok J (1992) Das Wettersteingebirge, Widerlager der allochtonen Inntaldecke, und die Ötztalmasse, 
Motor tertiärer posthumer NW-Bewegungen im Mieminger Gebirge. Geol-Paläontol Mitt Innsbruck 18:1-34

Frank W (1987) Evolution of the Austroalpine elements in the Cretaceous. In: Flügel HW, Faupl P (eds) Geodynamics of the Eastern Alps. Deuticke, Wien, pp 379-406

Frisch W (1979) Tectonic progradation and plate tectonic evolution of the Alps. Tectonophysics 60:121-139

Frisch W, Gawlick H-J (2003) The nappe structure of the central Northern Calcareous Alps and its disintegration during Miocene tectonic extrusion-a contribution to understanding the orogenic evolution of the Eastern Alps. Int J Earth Sci 92:712-727

Froitzheim N, Manatschal G (1996) Kinematics of Jurassic rifting, mantle exhumation, and passive-margin formation in the Austroalpine and Penninic nappes (eastern Switzerland). Geol Soc Am Bull 108:1120-1133. https://doi.org/10.1130/00167606(1996)108\%3c1120:KOJRME\%3e2.3.CO;2

Froitzheim N, Schmid S, Conti P (1994) Repeated change from crustal shortening to orogen parallel extension in the Austroalpine units of Graubünden. Eclogae Geol Helv 87:559-612. https:// doi.org/10.5169/seals-167471

Froitzheim N, Schmid SM, Frey M (1996) Mesozoic paleogeography and the timing of eclogite-facies metamorphism in the Alps: a working hypothesis. Eclogae Geol Helv 89:81-110. https:// doi.org/10.5169/seals-167895

Froitzheim N, Weber S, Nagel T, Ibele T, Furrer H (2012) Late Cretaceous extension overprinting a steep belt in the Northern Calcareous Alps (Schesaplana, Rätikon, Switzerland and Austria). Int J Earth Sci 101(5):1315-1329. https://doi.org/10. 1007/s00531-011-0717-4

Fruth I, Scherreiks R (1982) Hauptdolomit (Norian), stratigraphy, paleogeography and diagenesis. Sediment Geol 32:195-231. https://doi.org/10.1016/0037-0738(82)90050-1

Fruth I, Scherreiks R (1984) Hauptdolomit, sedimentary and paleogeographic models (Norian, Northern Calcareous Alps). Geol Rundsch 73(1):305-319

Fügenschuh B, Seward D, Mancktelow N (1997) Exhumation in a convergent orogen: the western Tauern window. Terra Nova 9:213-217. https://doi.org/10.1111/j.1365-3121.1997.tb000 15. $\mathrm{x}$

Fügenschuh B, Mancktelow NS, Seward D (2000) Cretaceous to Neogene cooling and exhumation history of the Ötztal-Stubai basement complex, eastern Alps: a structural and fission track study. Tectonics 19:905-918. https://doi.org/10.1029/2000T C900014

Ganss O (1967) Erläuterungen zum Blatt Nr. 8240 Marquartstein. Geologische Karte von Bayern 1:25000. Bayerisches Geologisches Landesamt, München

Gaupp R (1982) Sedimentationsgeschichte der kalkalpinen Mittelkreide (Allgäu, Tirol, Vorarlberg). Zitteliana 8:33-72

Gaupp R (1983) Die paläogeographische Bedeutung der Losensteiner Schichten (Alb, Nördliche Kalkalpen). Zitteliana 10:155-171

Gawlick H-J, Missoni S (2015) Middle Triassic radiolarite pebbles in the Middle Jurassic Hallstatt Mélange of the Eastern Alps: implications for Triassic-Jurassic geodynamic and paleogeographic reconstructions of the western Tethyan realm. Facies 61(3):13. https://doi.org/10.1007/s10347-015-0439-3

Gawlick H-J, Frisch W, Vecsei A, Steiger T, Böhm F (1999) The change from rifting to thrusting in the Northern Calcareous Alps as recorded in Jurassic sediments. Geol Rundsch 87:644-657

Gilluly J (1960) A folded thrust in Nevada-inferences as to time relations between folding and faulting. Am J Sci 258A:68-79

Golebiowski R (1991) Becken und Riffe der alpinen Obertriaslithostratigraphie und Biofazies der Kössener Formation. In: Nagel D, Rabeder G (eds) Exkursionen im Jungpaläozoikum und Mesozoikum Österreichs. Österreichische Paläontologische Gesellschaft, Wien, pp 79-119

Granado P, Roca E, Strauss P, Pelz K, Muñoz JA (2018) Structural styles in fold-and-thrust belts involving early salt structures: the Northern Calcareous Alps (Austria). Geology 47(1):51-54. https://doi.org/10.1130/G45281.1

Haas J, Kovács S, Krystyn L, Lein R (1995) Significance of Triassic facies zones in terrane reconstructions in the Alpine-North Pannonian domain. Tectonophysics 242:19-40. https://doi.org/10. 1016/0040-1951(94)00157-5

Haber G (1934) Bau und Entstehung der bayerischen Alpen. Deutsche Landschaftskunde, vol 3. C.H. Beck'sche Verlagsbuchhandlung, München

Hahn FF (1911) Ergebnisse neuerer Spezialforschungen in den deutschen Alpen. Geol Rundsch 2(4):207-219. https://doi.org/ 10.1007/BF01801888

Hahn FF (1912) Versuch einer Gliederung der austroalpinen Masse westlich der österreichischen Traun. Verhandlungen Der k k Geologischen Reichsanstalt 1912:337-344

Hahn FF (1913a) Grundzüge des Baues der nördlichen Kalkalpen zwischen Inn und Enns, I. Teil. Mitt Österr Geol Ges 9:238-357

Hahn FF (1913b) Grundzüge des Baues der nördlichen Kalkalpen zwischen Inn und Enns, II. Teil. Mitt Österr Geol Ges 9:374-500

Handy MR, Schmid SM, Bousquet R, Kissling E, Bernoulli D (2010) Reconciling plate-tectonic reconstructions of Alpine Tethys with the geological-geophysical record of spreading and subduction in the Alps. Earth Sci Rev 102(3):121-158. https://doi.org/10. 1016/j.earscirev.2010.06.002

Heißel W (1958) Zur Tektonik der Nordtiroler Kalkalpen. Mitt Österr Geol Ges 50(1957):95-132

Heißel G (1978) Karwendel—geologischer Bau und Versuch einer tektonischen Rückformung. Geol-Paläontol Mitt Innsbruck $8: 227-288$

Helmcke D, Pflaumann U (1971) Zur “Transgression” der mittleren Kreide im Westabschnitt der Nördlichen Kalkalpen (Vorarlberg, Österreich). Geol Palaeontol 5:149-163

Heydarzadeh K, Ruh JB, Vergés J, Hajialibeigi H, Gharabeigli G (2020) Evolution of a structural basin: numerical modelling applied to the Dehdasht Basin, Central Zagros, Iran. J Asian Earth Sci 187:104088. https://doi.org/10.1016/j.jseaes.2019. 104088

Hildebrandt E (2016) Strukturgeologischen Untersuchung in der Puitentalzone am Hohen Kamm östlich der Ehrwalder Alm. Unpublished Bachelor Thesis, Innsbruck

Höfle H-C, Kuhnert C, Bader K, Cramer C, Diez T, Schuch M, Hohenstatter E (1969) Erläuterungen zum Blatt Nr. 8331 Baiersoien. Geologische Karte von Bayern 1:25000. Bayerisches Geologisches Landesamt, München

Hornung T, Haas U (2017) Geologische Karte von Bayern 1:25.000, 8532/8632 Garmisch-Partenkirchen. Geologische Karte von Bayern 1:25.000. Bayerisches Geologisches Landesamt, München

Hückel B, Jacobshagen V, Stengel-Rutkowsky W (1961) Über den Bau des Allgäuer Hauptkammes und der Hornbachkette (Nördliche Kalkalpen). Zeitschr Dt Geol Ges 112(1960):91-104

Huckriede R (1958) Die Kreideschiefer bei Kaisers und Holzgau in den Lechtaler Alpen (Apt—unteres Cenoman). Verh Geol Bundesanst 1958:71-86

Hudec MR, Jackson MPA (2007) Terra infirma: Understanding salt tectonics. Earth Sci Rev 82(1):1-28. https://doi.org/10.1016/j. earscirev.2007.01.001

Humair F, Bauville A, Epard J-L, Schmalholz SM (2020) Interaction of folding and thrusting during fold-and-thrust-belt evolution: Insights from numerical simulations and application to the Swiss Jura and the Canadian Foothills. Tectonophysics 789:228474. https://doi.org/10.1016/j.tecto.2020.228474 
Jacobshagen V (1965) Die Allgäuschichten (Jura-Fleckenmergel) zwischen Wettersteingebirge und Rhein. Jb Geol Bundesanst 108:1-114

Janák M, Froitzheim N, Lupták B, Vrabec M, Krogh Ravna EJ (2004) First evidence for ultrahigh-pressure metamorphism of eclogites in Pohorje, Slovenia: Tracing deep continental subduction in the Eastern Alps. Tectonics 23:TC5014

Jerz H, Ulrich R (1966) Geologische Karte von Bayern 1:25.000, 8533/8633 Mittenwald. Geologische Karte von Bayern 1:25.000. Bayerisches Geologisches Landesamt, München

Kilian S, Ortner H (2019) Structural evidence of in-sequence and out-of-sequence thrusting in the Karwendel mountains and the tectonic subdivision of the western Northern Calcareous Alps. Austrian J Earth Sci 112(1):62-83. https://doi.org/10.17738/ajes. 2019.0005

Kilian S, Ortner H, Schneider-Muntau B (2021) Buckle folding in the Northern Calcareous Alps-field observations and numeric experiments. J Struct Geol 150:104416. https://doi.org/10.1016/j. jsg.2021.104416

Kley J (1996) Transition from basement-involved to thin-skinned thrusting in the Cordillera Oriental of Southern Bolivia. Tectonics 15:763-775

Kockel CW (1926) Die Deckenfalten der Hohenschwangauer Berge. Geol Rundsch 17(2):159-160. https://doi.org/10.1007/BF018 01862

Kockel CW, Richter M, Steinmann HG (1931) Geologie der Bayerischen Berge zwischen Lech und Loisach. Wissenschaftliche Veröffentlichungen Des DÖAV 10:231

Köhler M (1986) Lermooser tunnel (Ausserfern, Tirol): baugeologische verhältnisse, prognose und tektonische schlussfolgerungen. GeolPaläontol Mitt Innsbruck 13:363-379

Kövér S, Fodor L, Kovács Z, Klötzli U, Haas J, Zajzon N, Szabó C (2018) Late Triassic acidic volcanic clasts in different Neotethyan sedimentary mélanges: paleogeographic and geodynamic implications. Int J Earth Sci 107(8):2975-2998. https://doi.org/ 10.1007/s00531-018-1638-2

Kraus E (1957) Zum Verankerungs-Problem der kalkalpinen Decken im Bereich des Wetterstein-Gebirges. Zeitschr Dt Geol Ges 108(1956):141-155

Krauter E (1968) Zur Frage der Reliefüberschiebung an Staner-Joch (Östliches Karwendel, Tirol). Mitt Österr Geol Ges 60:23-64

Kreidl S (2015) Geologie und Tektonik am Westfuß der Zugspitze. unpubl. Master Thesis, Univ. Innsbruck, Innsbruck

Le Breton E, Brune S, Ustaszewski K, Zahirovic S, Seton M, Müller RD (2021) Kinematics and extent of the Piemont-Liguria Basin-implications for subduction processes in the Alps. Solid Earth 12(4):885-913. https://doi.org/10.5194/se-12-885-2021

Lein R (1987) Evolution of the Northern Calcareous Alps during Triassic times. In: Flügel HW, Faupl P (eds) Geodynamics of the Eastern Alps. Deuticke, Wien, pp 85-102

Leiss O (1988) Neue Wege zum Verständnis des kalkalpinen Deckenbaues als Konsequenz der Beckenanalyse intrakalkalpiner orogener Kreideserien. Documenta Naturae 43:95

Leiss O (1992) Orogenically controlled sedimentation in the Lechtaler Kreideschiefer (Lechtal shale; Cretaceous) and geodynamics of the inner western NCA (Northern Calcareous Alps; Lechtal Alps). Geol Rundsch 81:603-684

Leitner C, Spötl C (2017) Sect. 21-the Eastern Alps: multistage development of extremely deformed evaporites. In: Soto JI, Flinch JF, Tari G (eds) Permo-Triassic Salt Provinces of Europe, North Africa and the Atlantic Margins. Elsevier, Amsterdam, pp 467482. https://doi.org/10.1016/B978-0-12-809417-4.00022-7

Leo D (2020) Die Geologie der Hochwand im Mieminger Gebirge. Unpublished Bachelor Thesis, Univ. Innsbruck, Innsbruck
Leuchs K (1924) Der geologische Bau des Wettersteingebirges und seine Bedeutung für die Entwicklungsgeschichte der deutschen Kalkalpen. Zeitschr Dt Geol Ges 75(1923):100-113

Leuchs K (1930) Der Bau der Südrandstörung des Wettersteingebirges. Geol Rundsch 21(2):81-96. https://doi.org/10.1007/BF01802266

Leuchs K (1935) Tektonische Untersuchungen im Wettersteingebirge. Zeitschr Dt Geol Ges 87:703-719

Linzer H-G, Ratschbacher L, Frisch W (1995) Transpressional collision structures in the upper crust: the fold thrust belt of the Northern Calcareous Alps. Tectonophysics 242:41-61. https://doi.org/10. 1016/0040-1951(94)00152-Y

Mair G (2020) Die Geologie der Hohen Munde bei Telfs. Unpublished Bachelor Thesis, Univ. Innsbruck, Innsbruck

Malavieille J, Dominguez S, Lu C-Y, Chen C-T, Konstantinovskaya E (2021) Deformation partitioning in mountain belts: insights from analogue modelling experiments and the Taiwan collisional orogen. Geol Mag 158:84-103. https://doi.org/10.1017/S0016 756819000645

Manatschal G (2004) New models for evolution of magma-poor rifted margins based on a review of data and concepts from West Iberia and the Alps. Int J Earth Sci 93:432-466. https://doi.org/10.1007/ s00531-004-0394-7

Mandl G (2000) The Alpine sector of the Tethyan shelf - examples for Triassic to Jurassic sedimentation and deformation from the Northern Calcareous Alps. Mitt Österr Geol Ges 92:61-77

Mandl GW, Brandner R, Gruber A (2017) Zur Abgrenzung und Definition der Kalkalpinen Deckensysteme (Ostalpen, Österreich). In: Wimmer-Frey I, Römer A, Janda C (eds) Arbeitstagung 2017Angewandte Geowissenschaften an der GBA. Geologische Bundesanstalt, Wien, pp 254-255. https://doi.org/10.13140/RG.2.2. 24183.32166

May T, Eisbacher G (1999) Tectonics of the synorogenic "Kreideschiefer basin", northwestern Calcareous Alps, Austria. Eclogae Geol Helv 92:307-320. https://doi.org/10.5169/seals-168673

Mazzoli S, Pierantoni PP, Borraccini F, Paltrinieri W, Deiana G (2005) Geometry, segmentation pattern and displacement variations along a major Apennine thrust zone, central Italy. J Struct Geol 27:1940-1953. https://doi.org/10.1016/j.jsg.2005.06.002

McClay KR (1992) Glossary of thrust tectonics terms. In: McClay KR (ed) Thrust tectonics. Chapman \& Hall, London, pp 419-433

McDowell RJ (1997) Evidence for synchronous thin-skinned and basement deformation in the Cordilleran fold-thrust belt: the Tendoy Mountains, southwestern Montana. J Struct Geol 19(1):77-87. https://doi.org/10.1016/S0191-8141(96)00044-2

Meschede M (1994) Methoden der Strukturgeologie. Enke, Stuttgart

Miller H (1963a) Der Bau des westlichen Wettersteingebirges. Zeitschr Dt Geol Ges 113:409-425

Miller H (1963b) Die tektonischen Beziehungen zwischen Wettersteinund Mieminger Gebirge. N Jb Geol Paläont, Abh 118:291-320

Miller H (1963c) Gliederung und Altersstellung der jurassischen und unterkretazischen Gesteine am Südrand des WettersteinGebirges. Mitt Bayer Staatsslg Paläont Hist Geol 3:51-72

Miller H (1965) Die Mitteltrias der Mieminger Berge mit Vergleichen zum westlichen Wettersteingebirge. Verh Geol Bundesanst 1965:187-212

Molinaro M, Leturmy P, Guezou J-C, Frizon de Lamotte D, Eshraghi SA (2005) The structure and kinematics of the southeastern Zagros foldthrust belt, Iran: From thin-skinned to thick-skinned tectonics. Tectonics 24:TC3007. https://doi.org/10.1029/2004T $\mathrm{C} 001633$

Morley CK (1988) Out-of-sequence thrusts. Tectonics 7:539-561

Morlok J (1987) Die Geologie des westlichen Gaistals zwischen Wetterstein- und Mieminger Gebirge (Tirol, Nördliche Kalkalpen). unpubl. Diploma thesis, Frankfurt 
Moser M (2008a) Zusammenstellung ausgewählter Archivunterlagen der Geologischen Bundesanstalt, Blatt 118 - Innsbruck, GeoFAST 1:50.000 (Ausgabe 2008/09). Geologische Bundesanstalt, Wien

Moser M (2008b) Zusammenstellung ausgewählter Archivunterlagen der Geologischen Bundesanstalt, Blatt 119 - Schwaz, GeoFAST 1:50.000 (Ausgabe 2008/11). Geologische Bundesanstalt, Wien

Moser M (2010) Zusammenstellung ausgewählter Archivunterlagen der Geologischen Bundesanstalt, Blatt 116 - Telfs, GeoFAST 1:50.000 (Ausgabe 2011/04) Geologische Bundesanstalt, Wien

Müller K (1973) Das, Randcenoman" der Nördlichen Kalkalpen und seine Bedeutung für den Ablauf der ostalpinen Deckenüberschiebungen und ihrer Schubweiten. Geol Rundsch 62(1):54-96

Mutschlechner G (1954) Die Massengesteine der Nordtiroler und Vorarlberger Kalkalpen. Tschermaks Mineralogische Und Petrographische Mitteilungen 4(1):386-395. https://doi.org/10.1007/ bf01140410

Mutschlechner G (1955) Der Erzbergbau in Außerfern. Schlern-Schriften 111:25-52

Mylius H (1916) Ein Beitrag zum geologischen Bau des Wettersteingebirges. N Jb Min Geol Paläont 1916(1):10-40

Najafi M, Beamud E, Ruh J, Mouthereau F, Tahmasbi A, Bernaola G, Yassaghi A, Motamedi H, Sherkati S, Hassan Goodarzi MG, Vergés J (2020) Pliocene growth of the Dowlatabad syncline in Frontal Fars arc: folding propagation across the Zagros Fold Belt, Iran. GSA Bull. https://doi.org/10.1130/B35748.1

Neubauer F, Dallmeyer RD, Dunkl I, Schirnik D (1995) Late Cretaceous exhumation of the metamorphic Gleinalm dome, Eastern Alps: kinematics, cooling history and sedimentary response in a sinistral wrench corridor. Tectonophysics 242:79-98. https:// doi.org/10.1016/0040-1951(94)00154-2

Nowotny A, Pestal G, Rockenschaub M (1992) Die Landecker Quarzphyllit- und Phyllitgneiszone als schwächer metamorpher Anteil des Silvrettakristallins. Jb Geol Bundesanst 135:867-872

Oberhauser R (1995) Zur Kenntnis der Tektonik und Paläogeographie des Ostalpenraumes zur Kreide-, Paläozän- und Eozänzeit. Jb Geol Bundesanst 138:369-432

Olivetti V, Balestrieri ML, Faccenna C, Stuart FM, Vignaroli G (2010) Middle Miocene out-of-sequence thrusting and successive exhumation in the Peloritani Mountains, Sicily: Late stage evolution of an orogen unraveled by apatite fission track and (U-Th)/He thermochronometry. Tectonics 29(5):TC5005. https://doi.org/10. 1029/2009TC002659

Ortner H (2001) Growing folds and sedimentation of the Gosau Group, Muttekopf, Northern Calcareous Alps, Austria. Int J Earth Sci (geol Rundsch) 90:727-739. https://doi.org/10.1007/s005310000 182

Ortner H (2003a) Cretaceous thrusting in the western part of the Northern Calcareous Alps (Austria) — evidences from synorogenic sedimentation and structural data. Mitt Österr Geol Ges 94:63-77

Ortner H (2003b) Local and far field stress-analysis of brittle deformation in the western part of the Northern Calcareous Alps, Austria. Geol-Paläontol Mitt Innsbruck 26:109-131

Ortner H (2007) Styles of soft-sediment deformation on top of a growing fold system in the Gosau Group at Muttekopf, Northern Calcareous Alps, Austria: slumping versus tectonic deformation. Sediment Geol 196:99-118. https://doi.org/10.1016/j.sedgeo. 2006.05.028

Ortner H (2015) Fernerkundung mit Hilfe von Orthofotos und Geländemodellen in der Geologie-Beispiele aus den Nördlichen Kalkalpen. GeoAlp 11(2014):5-27

Ortner H (2016) Field Trip 4: Deep water sedimentation on top of a growing orogenic wedge-interaction of thrusting, erosion and deposition in the Cretaceous Northern Calcareous Alps. GeoAlp 13:141-182
Ortner H, Gaupp R (2007) Synorogenic sediments of the western Northern Calcareous Alps. GeoAlp 4:133-148

Ortner H, Reiter F, Acs P (2002) Easy handling of tectonic data: the programs TectonicVB for Mac and TectonicsFP for Windows(TM). Comput Geosci 28:1193-1200. https://doi.org/ 10.1016/S0098-3004(02)00038-9

Ortner H, Reiter F, Brandner R (2006b) Kinematics of the Inntal shear zone-sub-Tauern ramp fault system and the interpretation of the TRANSALP seismic section, Eastern Alps, Austria. Tectonophysics 414:241-258. https://doi.org/10.1016/j.tecto.2005.10. 017

Ortner H, Aichholzer S, Zerlauth M, Pilser R, Fügenschuh B (2015) Geometry, amount and sequence of thrusting in the Subalpine Molasse of Western Austria and Southern Germany. Eur Alps Tectonics 34(1):1-30. https://doi.org/10.1002/2014TC003550

Ortner H, Kositz A, Willingshofer E, Sokoutis D (2016) Geometry of growth strata in a transpressive fold belt in field and analogue model: Gosau Group at Muttekopf, Northern Calcareous Alps. Austria Basin Res 28(6):731-751. https://doi.org/10.1111/bre. 12129

Ortner H, Bitterlich L (2016) The Zugsitze cross section and the structure of the Northern Calcareous Alps. In: Ortner H (ed) Abstract Volume of GeoTirol2016 - annual meeting of DGGV and PANGEO Austria. Institute of Geology, University of Innsbruck, Innsbruck, p 248

Ortner H, Mayerl J, Tropper P, Steinacher R, Fügenschuh B, Cosca M, Schuster R (2006a) Geochronologische Untersuchung der Grenze Silvrettakristallin-phyllitgneiszone im Rätikon und Arlberggebiet: Hinweise auf die tektonische Beziehung zwischen beiden Komplexen. In: Tessadri-Wackerle M (ed) Abstracts Pangeo Austria 2006. innsbruck university press (IUP), Innsbruck, pp 229-230

Oswald P, Ortner H, Gruber A (2019) Deformation around a detached half-graben shoulder during nappe stacking (Northern Calcareous Alps, Austria). Swiss J Geosci 112(1):23-37. https://doi.org/10.1007/s00015-018-0333-4

Petschick R (1983) Sedimentpetrographie und sehr schwache Metamorphose mitteltriadischer Beckengesteine der zentralen Westlichen Kalkalpen (Bayern und Tirol). Mit geologischer Kartierung des Nordwestlichen Wettersteingebirges 1:10000. unpubl. Diploma thesis, Frankfurt

Petschick R (1989) Zur Wärmegeschichte im Kalkalpin Bayerns und Nordtirols (Inkohlung und Illit—Kristallinität). Frankfurter geowiss Arb, Serie C, Mineralogie 10:259 S

Pichler A (1866) Beiträge zur Geognosie Tirols. Jahrbuch Der k k Geologischen Reichsanstalt 16:503-504

Piller WE, Egger H, Erhart CW, Gross M, Harzhauser M, Hubmann B, van Husen D, Krenmayr H-G, Krystyn L, Lein R, Lukeneder A, Mandl GW, Rögl F, Roetzel G, Rupp C, Schnabel W, Schönlaub H-PS, H., Wagreich M, Wessely G (2004) Die stratigraphische Tabelle von Österreich 2004 (sedimentäre Schichtfolgen). Kommission für die paläontologische und stratigraphische Erforschung Österreichs der Österreichische Akademie der Wissenschaften und Österreichische Stratigraphische Kommission,

Pober E, Faupl P (1988) The chemistry of detrital chromian spinels and its implications for the geodynamic evolution of the Eastern Alps. Geol Rundsch 77:641-670

Ratschbacher L, Frisch W, Linzer G, Merle O (1991) Lateral extrusion in the Eastern Alps, part 2: structural analysis. Tectonics 10(2):257-271. https://doi.org/10.1029/90TC02623

Richter M (1956) Über den Bau der Vorarlberger Alpen zwischen Oberem Lech, Flexenpass und Ill. Zeitschr Dt Geol Ges 108(3):190-204. https://doi.org/10.1127/zdgg/108/1956/190 
Richter M (1929) Die Struktur der nördlichen Kalkalpen zwischen Rhein und Inn. Neues Jahrbuch für Mineralogie, Geologie und Paläontologie, Beilage-Band 63, Abteilung B:1-62

Risch H (1971) Stratigraphie der höheren Unterkreide der Bayerischen Kalkalpen mit Hilfe von Mikrofossilien. Palaeontographica, Abt A $138: 1-80$

Rockenschaub M (1990) Die tektonische Stellung der Landecker Quarzphyllit- und Phyllitgneiszone. Jb Geol Bundesanst 133:619-633

Rüffer T, Bechstädt T (1995) Interpretation des Deckenbaus in den westlichen nördlichen Kalkalpen: Widerspruch zwischen tektonischen und sedimentologischen Daten. Jb Geol Bundesanst 138:701-713

Sanders D (1996) The Upper Cretaceous near Maurach (Tyrol, Austria). Geol-Paläontol Mitt Innsbruck 21:123-151

Schenk V (1967) Die Faziesentwicklung der Reichenhaller Schichten und die Tektonik im Süden des Achensees. Tirol Geol Rundsch 56(1):464-473. https://doi.org/10.1007/BF01848736

Schidlowski M (1962) Über das westliche Ende der Allgäuer Hauptmulde im hinteren Bregenzerwald (Vorarlberger Kalkalpen). Verh Geol Bundesanst 1962:49-63

Schlagintweit O (1912a) Die Mieminger-Wetterstein Überschiebung. Geol Rundsch 3(2):73-92

Schlagintweit O (1912b) Zum Problem des Wettersteingebirges. Verhandlungen Der k k Geologischen Reichsanstalt 1912:313-327

Schmid SM, Fügenschuh B, Kissling E, Schuster R (2004) Tectonic map and overall architecture of the Alpine orogen. Eclogae Geol Helv 97:93-117. https://doi.org/10.1007/s00015-004-1113-x

Schmidegg O (1951) Die Stellung der Haller Salzlagerstätte im Bau des Karwendelgebirges. Jb Geol Bundesanst 94:159-205

Schmidt S, Hetzel R, Mingorance F, Ramos VA (2011) Coseismic displacements and Holocene slip rates for two active thrust faults at the mountain front of the Andean Precordillera $\left(\sim 33^{\circ} \mathrm{S}\right)$. Tectonics 30(5):TC5011. https://doi.org/10.1029/2011TC002932

Schmidt-Thomé P (1954) Klufttektonik und Grosstrukturen in den nördlichen Kalkalpen. Geol Rundsch 42(2):172-187. https:// doi.org/10.1007/bf01773956

Schneider H-J (1962) Bau des Wetterstein-und Mieminger Gebirges im Lichte von 100 Jahren geologischer Forschungsgeschichte. http://www.dav-bibliothek.de/webOPAC/01_Alpenvereins-Publi kationen/01_AV-Jahrbuch/AV_Jahrbuch_087.1962-web.pdf. Accessed 16 Nov 2021

Schuller V, Frisch W, Herzog U (2015) Critical taper behaviour and out-of-sequence thrusting on orogenic wedges - an example of the Eastern Alpine Molasse Basin. Terra Nova 27(3):231-237. https://doi.org/10.1111/ter.12152

Schuster R (2015) Zur Geologie der Ostalpen. Abh Geol Bundesanst 64:143-165

Schuster R, Koller F, Frank W (2007) Pebbles of upper-amphibolite facies amphibolites of the Gosau Group from the Eastern Alps: relics of a metamorphic sole? Bonn, p 74

Sieberer A-K, Ortner H (2018) Depositional setting of Cretaceous syntectonic sediments of the external Northern Calcareous Alps, Allgäu, Bavaria. In: Ustaszewski K, Grützner C, Navabpour P (eds) 17th symposion of tectonics, structural geology and crystalline geology 2018, 19-25 March 2018, Jena, Abstractbook. Druckzentrum FSU, Jena, p 114

Sieberer A (2020) Structural evolution of the northern Austroalpine margin, western Ammergau Alps, Bavaria. unpubl. Master thesis, Innsbruck

Sieniawska I, Aleksandrwski P, Rauch M, Koyi H (2010) Control of synorogenic sedimentation on back and out of sequence thrusting: insights from analog modeling of an orogenic front (Outer Carpathians, southern Poland). Tectonics 29:TC6012
Sommer P, Kositz A, Postl M, Mackowitz J, Ortner H (2010) Kinematik der kretazischen Faltung in den westlichen nördlichen Kalkalpen. PANGEO 2010, Abstracts. J Alpine Geol 52:231-232

Spang JH (1972) Numerical method for dynamic analysis of calcite twin lamellae. Geol Soc Am Bull 83(1):467-472. https://doi.org/ 10.1130/0016-7606(1972)83[467:NMFDAO]2.0.CO;2

Spengler E (1953) Versuch einer Rekonstruktion des Ablagerungsraumes der nördlichen Kalkalpen (1. Teil, Westabschnitt). Jb Geol Bundesanst 96:1-64

Spiess R (1985) Kristallingeologische und geochronologische Untersuchungen zur Entwicklungsgeschichte des Westrandes der Phyllitgneiszone i.w.S. im Montafon. unpublished PhD, Vienna

Spötl C (1988) Zur Altersstellung permoskythischer Gipse im Raum des ostlichen Karwendelgebirges. Geol-Paläontol Mitt Innsbruck 14(9):192-212

Spötl C (1989) The Alpine Haselgebirge Formation, Northern Calcareous Alps (Austria): Permo-Scythian evaporites in an alpine thrust system. Sediment Geol 65(1):113-125. https://doi.org/10.1016/ 0037-0738(89)90009-2

Stern G, Wagreich M (2013) Provenance of the Upper Cretaceous to Eocene Gosau Group around and beneath the Vienna Basin (Austria and Slovakia). Swiss J Geosci 106(3):505-527. https://doi. org/10.1007/s00015-013-0150-8

Stingl V (1982) Sedimentologie und Vererzung des alpinen Verrucano im Stanzertal (Tirol). Geol-Paläontol Mitt Innsbruck 12:71-80

Stingl V (1984) Lagerungsverhältnisse des Permoskyths im Stanzertal, West-Tirol. Österreich Mitt Geol Ges Bergbaustud 30(31):117-131

Strauss P, Granado P, Muñoz JA (2021) Subsidence analysis of salt tectonics-driven carbonate minibasins (Northern Calcareous Alps, Austria). Basin Res 33:968-990. https://doi.org/10.1111/ bre. 12500

Stüwe K, Schuster R (2010) Initiation of subduction in the Alps: continent or ocean? Geology 38:175-178. https://doi.org/10.1130/ G30528.1

Suppe J (1983) Geometry and kinematics of fault-bend folding. Am J Sci 283:684-721. https://doi.org/10.2475/ajs.283.7.684

Suppe J, Medwedeff DA (1990) Geometry and kinematics of faultpropagation folding. Eclogae Geol Helv 83:409-454

Tanner DC, Behrmann JH, Dresmann H (2003) Three-dimensional retrodeformation of the Lechtal nappe, Northern Calcareous Alps. J Struct Geol 25:737-748. https://doi.org/10.1016/S01918141(02)00057-3

Tollmann A (1970a) Der Deckenbau der westlichen Nord-Kalkalpen. N Jb Geol Paläont Abh 136:80-133

Tollmann A (1987) Late Jurassic/Neocomian gravitational tectonics in the Northern Calcareous Alps in Austria. In: Flügel HW, Faupl P (eds) Geodynamics of the Eastern Alps. Deuticke, Wien, pp $112-125$

Tollmann A (1970b) Tektonische Karte der Nördlichen Kalkalpen, 3. Teil: Der Westabschnitt. Mitt Österr Geol Ges 62 (1969):78-170

Tollmann A (1973) Grundprinzipien der alpinen Deckentektonik. Monographie der Nördlichen Kalkalpen, Teil I. Deuticke, Wien

Tollmann A (1976a) Analyse des klassischen nordalpinen Mesozoikums. Monographie der Nördlichen Kalkalpen, Teil II. Deuticke, Wien

Tollmann A (1976b) Der Bau der Nördlichen Kalkalpen. Monographie der Nördlichen Kalkalpen, Teil III. Deuticke, Wien

Trommsdorff V (1962) Über Lamprophyre aus den nördlichen Kalkalpen (Ehrwaldit). Tschermaks Mineralogische Und Petrographische Mitteilungen 8(2):281-325. https://doi.org/10.1007/ BF01131330

Trommsdorff V, Dietrich V, Flisch M, Stille P, Ulmer P (1990) Midcretaceous, primitive alkaline magmatism in the Northern 
Calcareous Alps: significance for Austroalpine geodynamics. Geol Rundsch 79(1):85-97. https://doi.org/10.1007/BF01830448

Trümpy R (1969) Die helvetischen Decken der Ostschweiz: Versuch einer palinspastischen Korrelation und Ansätze zu einer kinematischen Analyse. Eclogae Geol Helv 62:105-142. https://doi. org/10.5169/seals-163692

van Kooten WSMT (2016) The thrust between the Inntal and Lechtal nappe near the Nassereither Alm. Unpublished Bachelor Thesis, Univ. Innsbruck, Innsbruck

Verges J, Muñoz JA (1990) Thrust sequences in the southern central Pyrenees. Bull De Soc Geol De France 8:265-271

Vidal H (1953) Neue Ergebnisse zur Stratigraphie und Tektonik des nordwestlichen Wettersteingebirges und seines nördlichen Vorlandes. Geol Bav 17:56-88

von Eynatten H, Gaupp R (1999) Provenance of Cretaceous synorogenic sandstones in the Eastern Alps: constraints from framework petrography, heavy mineral analysis and mineral chemistry. Sediment Geol 124:81-111. https://doi.org/10.1016/S0037-0738(98) 00122-5

von Soos P, Engel J (2008) Eigenschaften Von Boden und Fels-Ihre Ermittlung im Labor. In: Witt KJ (ed) Grundbau-Taschenbuch. Ernst \& Sohn, Berlin, pp 123-218. https://doi.org/10.1002/97834 33600221.ch3
Weidich KF (1984) Feinstratigraphie, Taxonomie planktonischer Foraminiferen und Ökologie planktonischer Foraminiferengesamtfauna der kalkalpinen tieferen Oberkreide (Obercenoman - Untercampan) der Bayerischen Alpen. Abh Bayer Akad Wiss, math-naturwiss K1, NF 162:275 p.

Weissert HJ, Bernoulli D (1985) A transform margin in the Mesozoic Tethys: evidence from the Swiss Alps. Geol Rundsch 74:665679. https://doi.org/10.1007/BF01821220

Wesnousky SG, Kumar S, Mohindra R, Thakur VC (1999) Uplift and convergence along the Himalayan Frontal Thrust of India. Tectonics 18(6):967-976. https://doi.org/10.1029/1999tc900026

Winkler W (1988) Mid- to early late cretaceous flysch and melange formations. Paleotectonic implications. Jb Geol Bundesanst $131: 341-390$

Zacher W (1966) Die kalkalpinen Kreideablagerungen in der Umgebung des Tannheimer Tales (Außerfern, Tirol). Mit einem mikropaläontologischen Beitrag von F. BETTENSTAEDT. Mitt Bayer Staatsslg Paläont Hist Geol 6:213-228

Zambanini J (2014) Geologie der Zugspitze und Umgebung. unpubl. Master thesis, Univ. Innsbruck, Innsbruck

Zeil W (1955) Die Kreidetransgression in den Bayerischen Kalkalpen zwischen Iller und Traun. N Jb Geol Paläont Abh 101(1):141-226 